Published in final edited form as:

J Drug Target. 2015 August ; 23(0): 627-641. doi:10.3109/1061186X.2015.1048519.

\title{
Targeted polymeric nanoparticles for cancer gene therapy
}

\author{
Jayoung Kim ${ }^{1}$, David R. Wilson ${ }^{1}$, Camila G. Zamboni ${ }^{1,2,3}$, and Jordan J. Green ${ }^{1,4,5,6}$ \\ ${ }^{1}$ Department of Biomedical Engineering and the Translational Tissue Engineering Center, Johns \\ Hopkins University School of Medicine, Baltimore, MD, USA \\ ${ }^{2}$ Russell H. Morgan Department of Radiology and Radiological Science, Johns Hopkins Medical \\ Institutions, Baltimore, MD, USA \\ ${ }^{3}$ Instituto do Câncer do Estado de São Paulo, Hospital das Clínicas da Faculdade de Medicina da \\ Universidade de São Paulo, São Paulo, Brazil \\ ${ }^{4}$ Department of Materials Science and Engineering, Johns Hopkins University, Baltimore, MD, \\ USA \\ ${ }^{5}$ Department of Neurosurgery, Johns Hopkins University School of Medicine, Baltimore, MD, USA \\ ${ }^{6}$ Department of Ophthalmology, Johns Hopkins University School of Medicine, Baltimore, MD, \\ USA
}

\begin{abstract}
In this article, advances in designing polymeric nanoparticles for targeted cancer gene therapy are reviewed. Characterization and evaluation of biomaterials, targeting ligands, and transcriptional elements are each discussed. Advances in biomaterials have driven improvements to nanoparticle stability and tissue targeting, conjugation of ligands to the surface of polymeric nanoparticles enable binding to specific cancer cells, and the design of transcriptional elements has enabled selective DNA expression specific to the cancer cells. Together, these features have improved the performance of polymeric nanoparticles as targeted non-viral gene delivery vectors to treat cancer. As polymeric nanoparticles can be designed to be biodegradable, non-toxic, and to have reduced immunogenicity and tumorigenicity compared to viral platforms, they have significant potential for clinical use. Results of polymeric gene therapy in clinical trials and future directions for the engineering of nanoparticle systems for targeted cancer gene therapy are also presented.
\end{abstract}

\section{Keywords}

Cancer therapy; cell-specificity; gene delivery; nanoparticles; polymeric biomaterial; promoter; targeting ligands; tissue-specificity

\footnotetext{
Address for correspondence: Jordan J. Green, Department of Biomedical Engineering, Johns Hopkins University, Baltimore, MD 21231, USA. Tel: (410) 614-9113. green@jhu.edu.

Declaration of interest

This work was supported in part by the NIH (1R01EB016721). For graduate fellowship/scholarship support, JK thanks Samsung, DRW thanks the National Science Foundation, and CGZ thanks CAPES-Brazil.

The authors report no declarations of interest.
} 


\section{Introduction}

Molecular origins of many human diseases, such as cancer, are increasing being elucidated and understood on a genetic level. Gene therapy is an emerging technology that could treat these disorders by permanently or transiently replacing genetic defects with exogenous nucleic acids [1,2]. Nucleic acids can be used as new biological cancer therapeutics in multiple ways. For example, tumor suppressor genes can be upregulated or mutated oncogenes downregulated in affected cells, suicide genes can signal cell death, and DNA vaccines can trigger the immune system to fight cancer [3-6].

The challenge in gene therapy is to develop safe vectors that can efficiently deliver nucleic acids. Viral vectors, such as adenovirus and lentivirus, are highly effective yet liable to immunogenicity and/or tumorigenicity from insertional mutagenesis [7]. While non-viral gene delivery vectors are considered safe, this increased safety comes at the cost of lower efficiency. Polymeric vectors, both natural and synthetic, compose a class of non-viral vectors that show great promise as their chemical structure can be tuned to allow design flexibility for increased safety and efficacy.

A key component for cancer gene therapy success is delivery. While physical methods of delivery enhancement, such as using ultrasound, heat, light, and applied magnetic and electric fields, have been utilized to deliver gene carriers to target cancer sites, these methods rely on precise knowledge of the location of tumors. To reach both known and unknown locations of cancer cells, other research efforts have focused on the development of non-viral vectors, such as polymeric nanoparticles, as delivery systems to ensure sitespecific accumulation and cancer-specific transfection through both passive and active targeting [2]. As illustrated in Figure 1, small nanoparticles (or polyplexes) with neutral surface charge and steric hindrance can circulate for extended periods of time and accumulate near tumor sites through the enhanced permeation and retention (EPR) effect. In addition, polymeric biomaterials, with or without targeting ligands, can induce tissuespecific accumulation and cell-specific uptake. Finally, nucleic acid engineering can enable cell type-specific transcription and translation.

This review highlights advances to improve the targeted delivery of therapeutic nucleic acids through the utilization of polymeric nanoparticle vectors. The presented nanoparticles are able to specifically target and enhance efficient delivery to tumors.

\section{Biophysical and biomaterial-mediated targeting}

Intrinsic physicochemical characteristics of polymeric nano-particles can facilitate tumor targeting. Characteristics such as particle size, surface charge, and chemical functional groups exposed on a biomaterial's surface can either drive cellular uptake or block cellular interaction. In some cases, biomaterial composition can dictate tumor specificity in the absence of known ligands. The technology that enables passive targeting to cancer cells is an expanding area of research in the design of polymeric gene delivery vectors. 


\section{Biophysical targeting}

One of the most widely utilized mechanisms of passive targeting is based on size. The enhanced permeation and retention (EPR) effect, or leaky vasculature and a lack of lymphatic drainage around a tumor mass, allows for nanoparticles of less than $500 \mathrm{~nm}$ to accumulate in the regions of tumor vasculature [8,9]. Larger nanoparticles are usually eliminated from the body by the reticuloendothelial system (RES) or trapped in the lungs, while nanoparticles with hydrodynamic diameters smaller than $5 \mathrm{~nm}$ are rapidly excreted by the kidneys. To prevent particle aggregation and maintain the effective size for the EPR effect, nanoparticles are often coated with hydrophilic molecules, such as poly(ethylene glycol) (PEG) that provide neutral surface charge and steric hindrance [10-13].

Many polymeric nanoparticles for gene delivery are formed through electrostatic interactions between positively charged cationic polymers and negatively charged anionic DNA. The net balance of these charges determines a nanoparticle's surface charge, which is one of its key biophysical properties. A positively charged nanoparticle surface interacts with negative charges on the cellular membrane and promotes cellular uptake [14]. In addition, non-specific adsorption of anionic serum proteins on to positively charged surfaces of nanoparticles changes the surface properties of nanoparticles. In some cases, these interactions have the potential to induce receptor-mediated endocytosis [15-17]. Other studies have shown that adsorbed serum proteins can reduce cellular uptake [18]. Moreover, these non-specific protein interactions can induce particle aggregation and opsonization, thereby shortening systemic circulation and reducing the EPR effect and cancer-targeting potential.

To prevent undesirable particle-serum interactions, various methods have been explored to shield the surface of polymeric nanoparticles with biomolecules. One common strategy is the utilization of neutrally charged PEG molecules as previously discussed. Researchers have also made stimuli-responsive versions of PEG coatings that aid in tumor targeting. For example, with a stimuli-responsive linker, such as metalloproteinase-cleavable linker, PEG can detach from a nanoparticle surface, restore a positive nanoparticle surface charge in close proximity to cancer cells, and better interact with these target cells [19]. Other approaches for nanoparticle surface shielding have utilized other polyanions, such as poly(glutamic acid), carboxymethyl poly(L-histidine), and hyaluronic acid (HA) to coat positively charged nanoparticle surfaces, promote colloidal stability, and facilitate gene delivery in vitro and in vivo [20-25].

In addition to cationic polymer forming nanoparticles with DNA via electrostatic interaction, other hydrophobic polymers, such as poly(lactic-co-glycolic acid) (PLGA), are also used to encapsulate genetic cargo through emulsion [26-28]. Although many applications of this type are focused on microspheres that deliver DNA vaccines to macrophages and antigen presenting cells [29-34], Cohen et al. [35] showed controlled release of a reporter gene from PLGA nanoparticles. Other groups formulated hybrid PLGA nanoparticles with other cationic polymers, such as polyethylenimine (PEI) and poly( $\beta$ amino ester) (PBAE), to enhance DNA-loading efficiency and cellular internalization [36,37]. The surface of PLGA-PBAE blend DNA-encapsulating nanoparticles was further 
modified with cell-penetrating peptides to reduce cytotoxicity and increase nucleic acid delivery.

\section{Biomaterial-mediated targeting}

Many biomaterials have been investigated as polymeric vectors capable of delivering genetic cargo to cells of interest. Polymers used for gene delivery include polypeptides (i.e. poly(L-lysine)), natural polymers (i.e. chitosan, dextran, and HA), and synthetic polymers (i.e. PEI, polyamidoamine (PAMAM) and PBAE) [38-53]. Interestingly, some of these polymers have shown a bias for transfecting one cell type over another, indicating that they can enable tissue- or cell-specificity without an active targeting modification.

Tissue targeting and biodistribution of polymeric nano-particles is one of the key elements of pharmacokinetics in systemic delivery. Polymeric nanoparticles can demonstrate an intrinsic tendency to accumulate in particular organs or tissues. For example, dextran sulfate is able to bind to more receptors on liver sinusoidal endothelial cells than HA, and thus accumulates more in liver [54]. Biodistribution of PEI nanoparticles varies depending on the molecular weight, the structure of the polymer, and the polymer amine to DNA phosphate (N/P) ratio [55]. Polymer coatings can also generate tissue specificity as work by Harris et al. showed that PBAE nanoparticles coated with anionic poly(glutamic acid)-based peptides demonstrated changes in biophysical properties and tissue-specificity to spleen and bone marrow (Figure 2A) [56]. Such tissue specificity of biomaterials could potentially be utilized to target tumors as well.

Biomaterial-mediated targeting to specific cell-types has been demonstrated with PBAE polymeric nanoparticles. The physicochemical properties of PBAE nanoparticles can be tuned by the monomer composition used in the synthesis of the constituent polymers, and structure-function relationships have been extensively investigated [57-59]. For example, specific PBAE structures have significant specificity of transfecting cancer cells over their healthy counterparts as shown in Figure 2(B) and (C). PBAE nanoparticles show an order of magnitude higher transfection efficacy at transfecting human primary brain tumor initiating cells (BTICs) over primary fetal neural progenitor cells (fNPCs) and similarly at transfecting hepatoma cells over hepatocytes $[53,60]$. The authors also showed that the total uptake of nanoparticles as well as the division rate of the cells were similar between BTICs and fNPCs from multiple primary samples, indicating that other factors are the major contributors of the biomaterial-mediated specificity. This research highlights that differential biomaterial-cell interactions can occur in cancer cells as compared to healthy cells and can enable gene delivery specific to cancer cells. Further research is needed in this area of drug delivery to elucidate the mechanisms responsible for this nanoparticle targeting.

\section{Ligand targeting}

The most well-studied method to target cancer cells with polymeric nanoparticles is through the use of ligands conjugated to the surface of nanoparticles. Cancer results in the dysregulation of a large number of genes including many cell surface receptors, whose upregulation can be exploited for targeting via specific ligands. Transferrin [61-68], folate [69,70], epidermal growth factor (EGF) [71,72], RGD [73,74] and other peptides, HA 
$[75,76]$ and specific carbohydrates have been utilized as targeting moieties for selective polymeric nanoparticle delivery to tumor cells. Additionally, antibodies [77,78] and antibody fragments [79] have been utilized to target cancer specific antigens such as the HER2 receptor and prostate specific antigen. Many of the targeting moieties used for polymeric gene delivery to treat cancer have been previously utilized for the delivery of chemotherapeutics and in targeting of liposomes for gene delivery [80,81]. Among factors affecting whether conjugation of targeting ligands improves transfection efficiency are ligand density [70] and ligand-binding affinity [64,82] as well as effect on zeta potential and nanoparticle stability $[70,73,75]$. Ligand density can increase cooperative binding and avidity to improve cellular uptake.

\section{Transferrin}

Transferrin (Tf), an $80 \mathrm{kDa}$ glycoprotein, has been conjugated to nanoparticles containing poly(L-lysine) (PLL [61]), PEI [62,83], cyclodextrin [64], and PAMAM [66] to improve targeting to tumor cells overexpressing the Tf-receptor. Conjugation of transferrin to the surface of PEI and PEI-PEG nanoparticles for plasmid delivery has been shown to clearly improve tumor targeting and reduce off-target transfection as shown in Figure 3 [63]. Importantly, conjugation of Tf to the PEI-PEG nanoparticles was shown to improve tumor cell transfection at $48 \mathrm{~h}$, thus Tf was thought to improve the number of plasmids that reached each transfected cell [63]. These Tf-coated PEG-PEI nanoparticles were shown to transfect distant tumor cells in vivo 10-100 times greater compared to non-tumor cells following intravenous injection $[62,83]$. Transferrin has continued to be used in many nanoparticle formulations, notably as a component of cyclodextrin-PEG-Tf nanoparticles (CALAA-01) having undergone FDA Phase I clinical trials for the delivery of small interfering RNA (siRNA) to solid tumors [67].

\section{Folic acid}

Receptors for folate or folic acid (FA) are upregulated in rapidly dividing cell types, including tumor cells, and were proposed as an early target for drug delivery to cancer cells [84]. For gene delivery, folate has been used to target bPEI-PEG nanoparticles for improved uptake and tranfection with a reporter gene by folate receptor expressing cells both in vitro and in vivo [69]. Folate targeting for these nanoparticles was shown to improve transfection with minicircle DNA by approximately 3.6-fold in vivo although broad transfection was seen as folate receptors are expressed on the surface of most proliferating cells [69]. In another study, folic acid was notably shown to be the most effective targeting ligand to cancer cells among 30 (primarily peptides) ligand tested for delivery by oligonucleotidebased nanoparticles [70]. These oligonucleotide-based nanoparticles were shown to be effective for $\sim 60 \%$ knockdown of a reporter luciferase gene in a xenograft tumor model in vivo following IV administration [70].

\section{Epidermal growth factor}

The epidermal growth factor receptor (EGFR) is a common molecular target for cancer therapy overexpressed in approximately $30 \%$ of solid tumors in addition to being a predictor of poor treatment outcome [85]. EGF was conjugated to PEI-PEG as early as 2001 for 
improved transfection measured to be between 10 and 100 times greater than untargeted nanoparticle in vitro [71]. Since then, synthetic peptides designed to target the EGFR, including GE11, have been conjugated to linear PEI-PEG nanoparticles for the delivery of plasmids coding for a sodium iodine symporter gene for the treatment of liver cancer [72]. These EGFR targeted polymeric nanoparticles were shown to improve tumor specific transfection compared to non-targeted nanoparticles and increased survival demonstrating the potential efficacy of targeting ligands [72].

\section{RGD peptide}

The RGD peptide (arginine, glycine, aspartic acid) and other oligopeptide variations have been shown to strongly target the $\alpha_{v} \beta_{3}$ integrin receptor that is selectively expressed in tumor vasculature, with weaker binding to many other integrin receptors for improved cellular uptake [82]. Conjugation of RGD peptide and cyclic-RGD peptide to nanoparticles for targeted delivery of plasmids to tumor cells has also been shown to improve transfection in vivo one day following IV administration in mice, although there were notably near equal increases in transfection of cells in the lungs and liver [74]. For the plasmid delivery of bPEI-based nanoparticles, Sakae et al. designed an anionic version of PEG having conjugated succinic acid residues, PEG-suc, and RGD peptide, both of which increased transfection efficiency [74]. RGD peptide has also been electrostatically attached to PBAE nanoparticles for the delivery of DNA and shown to improve transfection of cells overexpressing integrin receptors but was not specifically applied to targeting tumor cells [73].

\section{Hyaluronic acid}

The CD44 cell receptor for HA is often overexpressed on tumor cells and is under active investigation for its putative role in cancer initiation/stem cells [86]. As a targeting moiety, HA can greatly affect zeta potential of the nanoparticles created depending on the amount used due to its negative charge at physiological $\mathrm{pH}$ [75]. Zwitterionic nanoparticles composed only of HA-bPEI in varying ratios have been explored for targeted transfection [75]. While these nanoparticles were not applied for targeting tumor cells specifically, they could be adapted for this purpose based on the use of HA in targeted delivery of chemotherapeutics to cancer cells $[75,76]$.

\section{Antibodies}

Antibodies can be used as efficient and specific targeting moieties for tumors expressing a tumor specific antigen such as HER2 [77] or prostate specific antigen [78]. The conjugation of HER2 antibodies to PEI for the delivery of DNA was shown to improve transfection of HER2+ breast cancer cell lines in vitro 20-fold [77]. Antibodies for prostate specific membrane antigen have also been used to target PEI/DNA nanoparticles to prostate cancer cells in vivo with 20-fold improvement over non-targeted nanoparticles [78]. Antibody fragments have also been used to target cancer cells; specifically, a fusion protein composed of HER2 single-chain fragmented antibodies and a cationic polypeptide for the delivery of siRNA to HER2+ breast cancer cells was shown to improve tumor targeting and reduce metastasis in vivo following multiple weekly tail vein injection [79]. Although antibodies 
can bind with high affinity, the use of monoclonal antibodies and antibody fragments as targeting ligands can be significantly more expensive than other cell receptor ligands and are not necessarily more effective. Antibody use for targeting of therapeutics has increased dramatically yet with high associated costs may not be the best strategy for targeted polymeric gene delivery [87].

\section{Transcriptional-level targeting}

For the case of DNA delivery, biological targeting of cancer cells can also be achieved following intracellular nanoparticle delivery. Although polymer, nanoparticle, and ligand properties are key to bind to target cells and lead to internalization by target cells, delivered DNA can be engineered to impart further cancer targeting on the intracellular level. To further constrain therapeutic transgene expression to just targeted cancer cells, and obviate undesirable effects associated with expression in healthy cells, transcriptional targeting can be utilized. Transcriptional targeting can be achieved by restricting the expression of transgenes to only tumors or particular tissues through the use of specific promoters [88].

\section{Transcriptional control of gene expression}

In eukaryotes, the transcription of protein-coding genes involves the interaction between RNA polymerase II, cis-regulatory DNA elements, transcription factors, co-factors and chromatin structure [89]. Cis-regulatory DNA elements refer to promoters and distal regulatory sequences that contain recognition sites for transcription factors (trans-acting elements) [90]. Promoters are located upstream from the transcriptional start site of a gene [91,92] and comprise a core promoter and proximal regulatory elements [90,93]. The binding of RNA polymerase II to the core promoter, which initiates transcription, requires general (basal) transcription factors [89]. Together, RNA polymerase II and general transcription factors form the preinitiation complex (PIC) [94], which provides only basal levels of transcription [95]. This basal machinery activity can be increased by the binding of other set of proteins, site-specific transcription factors, to the proximal and distal regulatory elements [95]. In contrast to the ubiquitous expression of general transcription factors, sitespecific transcription factors are expressed in a spatio-temporal and/or condition-specific manner [96]. This tight regulation is critical in determining where and to what extent a given gene is expressed [97]. Accordingly, a gene of interest will be expressed only in cells containing sufficient levels of the transcription factors involved in activating transcription from the promoter located upstream from this gene [88].

The regulation provided by the coordinated interaction between transcription factors is the primary mean by which cells orchestrate gene expression in response to various stimuli [98]. Thus, the cis-regulatory elements that recruit these factors can be used and tailored to drive transcription of an exogenously delivered therapeutic gene in a tissue- or tumor-specific manner $[98,99]$.

It is important to highlight that the transcriptional targeting strategy for gene therapy relies on the accurate delivery of DNA to the cells of interest, i.e. the gene under control of a specific promoter must reach the cells containing the right transcriptional factors; otherwise no transcription occurs. Thus, the efficiency of the control at the transcriptional level is 
highly dependent on other levels of targeting, i.e. delivery to specific cells. Moreover, cell surface binding, endosomal escape, translocation to the nucleus, and nucleic acid release also represent barriers that have to be overcome in order to a gene reaches the transcription machinery [100].

\section{Promoters for transcriptional targeting}

\section{Tissue-specific promoters}

The application of tissue-specific promoters in transcriptional targeting exploits genes that are specifically expressed in a tissue of interest [99]. If a particular promoter is active in certain healthy tissues in addition to tumor cells, then the ability for cancer targeting is reduced. One of the first tissue-specific promoters evaluated for transcriptional targeting in cancer gene therapy was the promoter for the tyrosinase gene, which is preferentially active in melanocytes [101]. In 1993, Vile et al. [101] showed that this promoter can drive expression of a reporter gene to both human and murine melanoma cells and melanocytes, but not to a range of other cell types. Since then, the tyrosinase promoter has been extensively applied in the research of gene therapy for melanoma [102-105]. Similarly, in the past two decades, candidates of prostate specificity, such as prostate-specific antigen (PSA [106]), prostate-specific membrane antigen (PSMA [107]), and probasin [108], have been widely explored. Tissue-specific promoters have also been applied to drive siRNA expression in target cells. Song et al. [109] demonstrated that the siRNA expression driven by the prostate-specific antigen (PSA) promoter can lead to gene silencing specifically in the androgen-responsive prostate cancer cell line, in an androgen-dependent and tissue-specific manner.

\section{Tumor-specific promoters}

Tumor-specific promoters are involved in the transcription of genes that are overexpressed in tumor cells but have limited or no activity in normal cells [99]. Cancer-specific promoters can be specific to a particular cancer type [98] or general to many types of cancer without a particular tissue specificity [110,111]. The progression-elevated gene-3 (PEG-3) [112], for example, was identified as a mutant gene overexpressed during tumorigenesis of different cancer types that presents tumor progression promoting properties. The PEG-3 promoter was shown to drive cancer-specific gene expression and cell killing, while sparing normal cells [112,113]. Applying in vivo jetPEI (Polyplus transfection SA, Illkirch, France) as a vector for intravenous administration, Hyo-eun et al. successfully demonstrated PEG-3 promoter-driven firefly luciferase expression (PEG-Luc) specifically to small meta-static deposits of human melanoma and breast cancer in mouse models (Figure 4) [114]. Other relevant cancer-specific promoters include the human telomerase reverse transcriptase (hTERT) [115], survivin [116,117], and astrocyte elevated gene-1 (AEG-1) [118,119] promoters.

Tumor-selective promoters can take advantage of fetal genes that become re-expressed in certain malignancies [110,111], such as the promoters of the oncofetal a-fetoprotein (AFP) and carcinoembryonal antigen (CEA) genes, reactivated in hepatocellular carcinomas (HCC) and adenocarcinomas, respectively [99]. Hu et al. used a construct with the fragment EA4D 
of the AFP promoter and a novel polymeric delivery system to induce cell killing mediated by tBid overexpression only in AFP-producing HCC [120]. Other tumor-selective promoters are also able to induce gene expression only in particular cancer types. Huang et al. tested PBAE-mediated delivery of a construct containing the diphtheria toxin suicide protein (DTA) gene under control of two promoters of genes that are highly active in ovarian tumors, MSLN and HE4 [121]. The authors observed suppression of ovarian tumor growth following intraperitoneal (i.p.) injection of particles twice a week, while minimal nonspecific toxicity was observed in other tissues. Other groups have also explored promoters of genes whose activity is related to additional cancer hallmarks [98,99,110,111], such as the hypoxic tumor environment [122], the proliferating endothelium of tumor blood vessels [123], the altered signaling pathways [124], and the cell-cycle abnormalities and hyperproliferation [125].

\section{Inducible promoters}

In contrast to tissue/tumor-specific promoters, which usually induce constitutive transgene expression in a target tissue [99], inducible promoters can be applied to achieve temporal, spatial $[126,127]$ and dose-dependent regulation $[128,129]$. These promoters can be regulated by agents such as drugs, radiation and heat [111]. An example of such a promoter is the early growth response gene-1 (Egr-1) promoter, which is radiation-induced and has been used to optimize the control of gene expression in different tissues [130-133].

Inducible promoters essentially drive ubiquitous transgene expression [134], however, tissue/tumor-specific and inducible promoters can be combined to enable the control of transgene expression in a tissue/tumor specific and inducible manner [134-136]. Recently, Xiong et al. [131] successfully combined the hTERT promoter to CArG elements, which is known to be the radiation-responsive motifs within the Egr1 promoter [137], to drive radiation-inducible and cancer-specific gene expression. The synthetic promoter containing six repeating $\mathrm{CArG}$ units (C6) showed the best radiation inducibility.

\section{Design of stronger promoters}

As shown in some of the examples described above, a composite promoter can be engineered by incorporating different functional elements from natural promoters [98]. These strategies aim to optimize the natural promoter systems and to overcome the generally weak transcriptional activity of eukaryotic promoters, while maintaining specificity $[99,110,111]$.

\section{Post-transcriptional targeting}

Controlled expression of factors encoded by exogenously delivered DNA can also be targeted to cancer cells by post-transcriptional targeting. The expression of transgenes can be regulated post-transcriptionally by controlling RNA splicing, RNA stability, and translation initiation [90]. 


\section{RNA splicing}

RNA splicing consists of the removal of introns and coupling of exons from the pre-mRNA transcripts to form mRNA before its transport to the cytoplasm [138]. The variation of the splicing sites within a transcript, called alternative RNA splicing, generates multiple mRNA isoforms in different cell types, tissues, or stages of development [139]. Changes in alternative RNA splicing are commonly observed in malignancies [140-142]. The alternative RNA splicing events involved on the expression of the CD44 gene, for example, generate mRNA isoforms called CD44R1, which exists on activated and/or malignant cell types. Only CD44R1-positive cells contain the necessary machinery to accurately splice a particular intron within the CD44 pre-mRNA. Hayes et al. observed that constructs in which the expression of a transgene is dependent upon removal of this intron from the sequence can be used to specifically target CD44R1-positive cells [140].

\section{RNA stability}

The stability of mRNA molecules and their decay rates are determined by regulatory elements within the mRNA sequence and proteins or small non-coding RNAs that bind these elements [143]. The post-transcriptional regulation mechanism by which small non-coding RNAs interact with specific mRNAs and induce selective gene silencing is called RNA interference (RNAi) [143,144]. siRNAs perform RNAi by degrading mRNAs containing fully complementary sequences and by translation repression [145]. siRNA-mediated silencing has been applied to target genes associated with various cancer-relevant pathways [146], such as apoptosis (e.g. Bax [147] and Bcl-2 [148]) and cell signaling (e.g. K-Ras [149]), and to knockdown viral oncogenes (e.g. HPV E6 [150]). Recently, Urban-Klein et al. demonstrated significant growth inhibition following siRNA-mediated silencing of the HER-2 proto-oncogene [151], which is overexpressed in a variety of human cancers [152154] and related with poor prognosis [154]. Micro-RNA (miRNA) delivery for tumor targeting can cause inhibition of oncogenic nucleic acids or be used to replace tumor suppressor miRNAs [155]. miR-34 and let-7 are tumor-suppressor miRNAs [155] with reduced expression levels in many types of cancer cells [156-159]. Replacement therapy with miR-34 has been shown to successfully induce apoptosis in cancer cell lines [160] while let-7 replacement can inhibit tumor growth [161]. On the other hand, the knockdown of miR-155, overexpressed in many solid malignancies, has demonstrated to inhibit tumor growth, migration and invasion [162]. Short hairpin RNAs (shRNA), which are transcribed in the nucleus, can be effective to target cancer cells when under control of efficient promoters [163]. Gao et al. [122] demonstrated silencing of an oncogene serine/threonine kinase specifically in hepatoma cells by shRNA under control of AFP promoter/hypoxiainducible enhancer.

\section{RNA translation}

The translation initiation process consists of the recruitment and assembling of the initiator tRNA and the $40 \mathrm{~S}$ and $60 \mathrm{~S}$ ribosomal subunits at the start codon of the mRNA molecule [164]. Excessive secondary structures in the $5^{\prime}$ untranslated region (UTR) of the mRNA are normally inefficiently translated [165]. However, overexpression of the eIF4E factor, a ratelimiting component of translation initiation, results in a specific increase in the translation of 
highly structured $5^{\prime}$ UTR mRNAs [166,167]. eIF4E is commonly overexpressed in solid tumors [168-170] and many of the mRNAs with excessive secondary structures encode products that stimulate cell growth and angiogenesis [171] (e.g.: fibroblast growth factor-2; FGF-2 [166,171]). DeFatta et al. [166] found that the $5^{\prime}$ UTR of FGF-2 mRNA can be placed in front of the herpes simplex virus type 1 thymidine kinase (HTK) gene to restrict the translation of HTK mRNA and, therefore, the susceptibility of the prodrug ganciclovir, to cancer cells.

\section{Other targeting strategies that can be utilized in polymeric nanoparticle- mediated cancer gene therapy}

The choice of the gene product to be expressed itself can introduce another level of tumor specificity for cancer gene therapy. Polymeric gene therapy can be used to restore function of tumor suppressor genes that have been inactivated during tumorigenesis, such as $\mathrm{p} 53$, by reintroducing the wild type gene into tumor cells $[172,173]$. The delivery of constructs encoding the TNF-related apoptosis-inducing ligand (TRAIL) gene represents another strategy of cancer targeting. TRAIL has the unique capacity of inducing apoptosis specific in cancer cells $[174,175]$. This cancer specificity involves enhanced activity of pro-apoptotic receptors (DR4 and DR5) in tumor cells and apoptotic priming of cancer cells by oncogenes [176].

An alternative method of active tumor targeting can be achieved by the capacity of mesenchymal stem cells (MSCs), such as the human adipose-derived MSCs (hAMSCs), to migrate towards tumors [177-179]. MSCs can be used as a cell-based therapeutic delivery vehicle following gene delivery with DNA-encoded anti-cancer molecules. For example, MSCs can be engineered with genes that encode differentiation agents such as bone morphogenetic protein-4 (BMP-4), which promotes the terminal differentiation of putative cancer stem cells (CSCs) and facilitates tumor eradication [180-182]. This MSC plus gene therapy approach has proven to be useful in treating glioblastomas to induce brain tumorinitiating cell (BTIC) differentiation and prolong survival in mice [183].

\section{Clinical trials}

The translation of polymeric gene delivery nanoparticles for cancer treatment has proved challenging and few polymeric nanoparticle formulations have yet made it to clinical trials. Table 1 lists selected polymeric nanoparticles used in clinical trials. Phase I/II clinical trials listed in Table 1 were designed to evaluate safety, dose-response pharmacodynamics, dosedependent accumulation of nanoparticles in tumor tissue, and show a signal of efficacy [68]. Multiple clinical trials have been undertaken using the PEI delivery system for diphtheriatoxin A termed BC-819 and developed by BioCancell Ltd. [184] Other PEI-based nanoparticle formulations have utilized glycosylated JetPEI [185] and PEG-PEI-cholesterol [186]. The genes chosen for delivery included DCK::UMK to increase chemosensitivity of tumor cells to gemcitabine, SSTR2 to inhibit tumor cell proliferation as well as IL-12 to induce anticancer activity from the patient's immune system [185]. PEI has also been evaluated in a clinical trial for the dual delivery of siRNA and plasmid DNA for treating a number of hematopoietic cancers [187]. These phase I/II trials are notable for demonstrating 
RNAi and delivery of plasmid DNA using polymeric vectors, as well as preliminary clinical evidence of gene therapy efficacy in preventing tumor growth in patients. Clinical trials on polymeric-based gene therapy are relatively recent; the great majority of these trials are ongoing and results have not yet been published. The cyclodextrin-PEG-Tf nanoparticle formulation, termed CALAA-01 was the first polymeric vector for siRNA delivery to enter a Phase I trial in 2008 [67]. This trial evaluated the safety of the CDP-based nanoparticle system to deliver siRNA to patients with solid cancers via systemic administration. A preliminary report from three patients presenting metastatic melanoma demonstrated encouraging results including dose-dependent accumulation of targeted nanoparticles in tumors and specific gene inhibition (siRNA-mediated M2 subunit of ribonucleotide reductase silencing) [68].

\section{Conclusion and future prospects}

Targeted polymeric gene delivery for cancer therapy has made advances through rational engineering of biomaterials, utilization of targeting ligands, and engineering of nucleic acids for transcriptional and translational regulation. Table 2 summarizes the three different methods of targeting polymeric nanoparticles to tumors with representative examples. In some ways, targeted gene therapy has followed similar improvements to delivery as nanoparticle-based chemotherapeutic formulations. Cancer is a disease well-suited for nanoparticle-based gene delivery strategies due to the multiple levels of targeting that can specifically treat cancer cells over healthy cells. These include opportunities for passive targeting via the EPR effect and active ligand targeting due to the changes in expression patterns of many cancer cell receptors. Polymeric nanoparticles can be readily engineered with active targeting moieties on their surfaces and produced on the scales required for pharmaceutical applications. Selection of biomaterials through broad polymer library screens and rational polymer engineering designs have both been utilized to improve tissue and tumor cell specificity as well improve transfection efficacy. Furthermore, polymer structures can be readily modified with PEG and other biomolecules for charge shielding and to improve tumor cell specificity and transfection in vivo. Compared to nanoparticle chemotherapeutic formulations, gene therapy possesses the additional level of targeting afforded in transcriptional and translational control for even greater reduction in off-target effects and potential reduction of side effects during the treatment. Systemic delivery and tissue targeting improvements through charge shielding and targeting moieties will continue to improve efficacy for intravenous administration. Improvements to nanoparticle stability in blood serum and reduction of alternative complement pathway activation for increased circulation time are also important aspects for improved systemic polymeric gene delivery. Although PEG is often used as a moiety to improve the stealth nature of nanoparticles, depending on how it is utilized, it may not be devoid of complement activation and can lead to hypersensitivity reactions [188]. Targeting at the cellular level can be improved by identification of receptors and ligands that lead to improved uptake, delivery to the cytoplasm, and intracellular trafficking leading to efficient transfection. Increased understanding of endocytosis and resulting endosome trafficking pathways will lead to more rational design of targeting moieties for improved intracellular delivery. Additionally, 
determination of differences in transfection between tumor cells and healthy cells following equal levels of nanoparticle uptake will allow improved design of nanoparticles.

Tissue- and tumor-specific promoters for transcriptional targeting and RNAi for gene knockdown have become key elements of non-viral gene therapy for cancer. Ongoing research will improve understanding of cancer cell-selective gene activity and enable the recognition of more potent regulatory components to drive cancer cell-specific gene expression and silencing. For the most effective cancer-cell targeting, these orthogonal systems for cancer specificity of polymeric gene delivery nanoparticles can be combined together.

Polymeric nanoparticle-based cancer gene therapy is still in its infancy at the clinical level but has great potential for the future. Compared to gene therapies utilizing viral vectors, polymeric nanoparticle-based approaches to gene therapy have lagged in transfection efficacy but have improved safety, lower risks of immunogenicity and tumorigenesis, improved manufacturing and quality control, improved targeting capabilities, and much greater nucleic acid carrying capacity. With advances in transfection efficacy and tumor specificity through multiple targeting strategies, polymeric nanoparticle-based gene therapy has a bright future.

\section{References}

1. Viola JR, El-Andaloussi S, Oprea II, Smith CI. Non-viral nanovectors for gene delivery: factors that govern successful therapeutics. Expert Opin Drug Deliv. 2010; 7:721-35. [PubMed: 20367531]

2. Jafari M, Soltani M, Naahidi S, et al. Nonviral approach for targeted nucleic acid delivery. Curr Med Chem. 2012; 19:197-208. [PubMed: 22320298]

3. Rice J, Ottensmeier CH, Stevenson FK. DNA vaccines: precision tools for activating effective immunity against cancer. Nat Rev Cancer. 2008; 8:108-20. [PubMed: 18219306]

4. Zarogoulidis P, Darwiche K, Sakkas A, et al. Suicide gene therapy for cancer - current strategies. J Genet Syndr Gene Ther. 2013; 4:1-13. http://dx.doi.org/10.4172/2157-7412.1000139.

5. Yadav S, van Vlerken LE, Little SR, Amiji MM. Evaluations of combination MDR-1 gene silencing and paclitaxel administration in biodegradable polymeric nanoparticle formulations to overcome multidrug resistance in cancer cells. Cancer Chemother Pharmacol. 2009; 63:711-22. [PubMed: 18618115]

6. Prabha S, Labhasetwar V. Nanoparticle-mediated wild-type p53 gene delivery results in sustained antiproliferative activity in breast cancer cells. Mol Pharm. 2004; 1:211-19. [PubMed: 15981924]

7. Pack DW, Hoffman AS, Pun S, Stayton PS. Design and development of polymers for gene delivery. Nat Rev Drug Discov. 2005; 4:581-93. [PubMed: 16052241]

8. Petros RA, DeSimone JM. Strategies in the design of nanoparticles for therapeutic applications. Nat Rev Drug Discov. 2010; 9:615-27. [PubMed: 20616808]

9. Torchilin V. Tumor delivery of macromolecular drugs based on the EPR effect. Adv Drug Deliv Rev. 2011; 63:131-5. [PubMed: 20304019]

10. Harris JM, Martin NE, Modi M. Pegylation: a novel process for modifying pharmacokinetics. Clin Pharmacokinet. 2001; 40:539-51. [PubMed: 11510630]

11. van Vlerken LE, Vyas TK, Amiji MM. Poly(ethylene glycol)-modified nanocarriers for tumortargeted and intracellular delivery. Pharm Res. 2007; 24:1405-14. [PubMed: 17393074]

12. Ogris M, Brunner S, Schuller S, et al. PEGylated DNA/transferrin-PEI complexes: reduced interaction with blood components, extended circulation in blood and potential for systemic gene delivery. Gene Ther. 1999; 6:595-605. [PubMed: 10476219] 
13. Boylan NJ, Suk JS, Lai SK, et al. Highly compacted DNA nanoparticles with low MW PEG coatings: in vitro, ex vivo and in vivo evaluation. J Control Release. 2012; 157:72-9. [PubMed: 21903145]

14. Verma A, Stellacci F. Effect of surface properties on nanoparticle-cell interactions. Small. 2010; 6:12-21. [PubMed: 19844908]

15. Khan JA, Pillai B, Das TK, et al. Molecular effects of uptake of gold nanoparticles in HeLa cells. Chembiochem. 2007; 8:1237-40. [PubMed: 17569092]

16. Dutta D, Sundaram SK, Teeguarden JG, et al. Adsorbed proteins influence the biological activity and molecular targeting of nanomaterials. Toxicol Sci. 2007; 100:303-15. [PubMed: 17709331]

17. Chithrani BD, Ghazani AA, Chan WC. Determining the size and shape dependence of gold nanoparticle uptake into mammalian cells. Nano Lett. 2006; 6:662-8. [PubMed: 16608261]

18. Patel PC, Giljohann DA, Daniel WL, et al. Scavenger receptors mediate cellular uptake of polyvalent oligonucleotide-functionalized gold nanoparticles. Bioconjug Chem. 2010; 21:2250-6. [PubMed: 21070003]

19. Li J, Ge Z, Liu S. PEG-sheddable polyplex micelles as smart gene carriers based on MMPcleavable peptide-linked block copolymers. Chem Commun (Camb). 2013; 49:6974-6. [PubMed: 23802223]

20. Zhou J, Liu J, Cheng CJ, et al. Biodegradable poly(amine-co-ester) terpolymers for targeted gene delivery. Nat Mater. 2012; 11:82-90. [PubMed: 22138789]

21. Peng SF, Yang MJ, Su CJ, et al. Effects of incorporation of poly(gamma-glutamic acid) in chitosan/DNA complex nanoparticles on cellular uptake and transfection efficiency. Biomaterials. 2009; 30:1797-808. [PubMed: 19110309]

22. Kurosaki T, Kitahara T, Fumoto S, et al. Ternary complexes of pDNA, polyethylenimine, and gamma-polyglutamic acid for gene delivery systems. Biomaterials. 2009; 30:2846-53. [PubMed: 19232715]

23. Green JJ, Chiu E, Leshchiner ES, et al. Electrostatic ligand coatings of nanoparticles enable ligandspecific gene delivery to human primary cells. Nano Lett. 2007; 7:874-9. [PubMed: 17362046]

24. Gu J, Wang X, Jiang X, et al. Self-assembled carboxymethyl poly (L-histidine) coated poly (betaamino ester)/DNA complexes for gene transfection. Biomaterials. 2012; 33:644-58. [PubMed: 22030282]

25. Ito T, Yoshihara C, Hamada K, Koyama Y. DNA/polyethylenei-mine/hyaluronic acid small complex particles and tumor suppression in mice. Biomaterials. 2010; 31:2912-18. [PubMed: 20047759]

26. Ando S, Putnam D, Pack DW, Langer R. PLGA microspheres containing plasmid DNA: preservation of supercoiled DNA via cryopreparation and carbohydrate stabilization. J Pharm Sci. 1999; 88:126-30. [PubMed: 9874713]

27. Hsu YY, Hao T, Hedley ML. Comparison of process parameters for microencapsulation of plasmid DNA in poly(D,L-lactic-co-glycolic) acid microspheres. J Drug Target. 1999; 7:313-23. [PubMed: 10682910]

28. Labhasetwar V, Bonadio J, Goldstein S, et al. A DNA controlled-release coating for gene transfer: transfection in skeletal and cardiac muscle. J Pharm Sci. 1998; 87:1347-50. [PubMed: 9811488]

29. Wang D, Robinson DR, Kwon GS, Samuel J. Encapsulation of plasmid DNA in biodegradable poly(D,L-lactic-co-glycolic acid) microspheres as a novel approach for immunogene delivery. $\mathrm{J}$ Control Release. 1999; 57:9-18. [PubMed: 9863034]

30. Tinsley-Bown AM, Fretwell R, Dowsett AB, et al. Formulation of poly(D,L-lactic-co-glycolic acid) microparticles for rapid plasmid DNA delivery. J Control Release. 2000; 66:229-41. [PubMed: 10742583]

31. Walter E, Dreher D, Kok M, et al. Hydrophilic poly(D,L-lactide-co-glycolide) microspheres for the delivery of DNA to human-derived macrophages and dendritic cells. J Control Release. 2001; 76:149-68. [PubMed: 11532321]

32. Benoit MA, Ribet C, Distexhe J, et al. Studies on the potential of microparticles entrapping pDNApoly(aminoacids) complexes as vaccine delivery systems. J Drug Target. 2001; 9:253-66. [PubMed: 11697029] 
33. Hedley ML, Curley J, Urban R. Microspheres containing plasmid-encoded antigens elicit cytotoxic T-cell responses. Nat Med. 1998; 4:365-8. [PubMed: 9500615]

34. Lunsford L, McKeever U, Eckstein V, Hedley ML. Tissue distribution and persistence in mice of plasmid DNA encapsulated in a PLGA-based microsphere delivery vehicle. J Drug Target. 2000; 8:39-50. [PubMed: 10761644]

35. Cohen H, Levy RJ, Gao J, et al. Sustained delivery and expression of DNA encapsulated in polymeric nanoparticles. Gene Ther. 2000; 7:1896-905. [PubMed: 11127577]

36. Fields RJ, Cheng CJ, Quijano E, et al. Surface modified poly(beta amino ester)-containing nanoparticles for plasmid DNA delivery. J Control Release. 2012; 164:41-8. [PubMed: 23041278]

37. Bivas-Benita M, Romeijn S, Junginger HE, Borchard G. PLGA-PEI nanoparticles for gene delivery to pulmonary epithelium. Eur J Pharm Biopharm. 2004; 58:1-6. [PubMed: 15207531]

38. Wagner E, Plank C, Zatloukal K, et al. Influenza virus hemagglutinin HA-2 N-terminal fusogenic peptides augment gene transfer by transferrin-polylysine-DNA complexes: toward a synthetic virus-like gene-transfer vehicle. Proc Natl Acad Sci USA. 1992; 89:7934-8. [PubMed: 1518816]

39. Wagner E, Cotten M, Foisner R, Birnstiel ML. Transferrin-polycation-DNA complexes: the effect of polycations on the structure of the complex and DNA delivery to cells. Proc Natl Acad Sci USA. 1991; 88:4255-9. [PubMed: 2034670]

40. Meyer M, Dohmen C, Philipp A, et al. Synthesis and biological evaluation of a bioresponsive and endosomolytic siRNA-polymer conjugate. Mol Pharm. 2009; 6:752-62. [PubMed: 19348503]

41. Rojanarata T, Opanasopit P, Techaarpornkul S, et al. Chitosan-thiamine pyrophosphate as a novel carrier for siRNA delivery. Pharm Res. 2008; 25:2807-14. [PubMed: 18563539]

42. Mao HQ, Roy K, Troung-Le VL, et al. Chitosan-DNA nanoparticles as gene carriers: synthesis, characterization and transfection efficiency. J Control Release. 2001; 70:399-421. [PubMed: 11182210]

43. Cohen JL, Schubert S, Wich PR, et al. Acid-degradable cationic dextran particles for the delivery of siRNA therapeutics. Bioconjug Chem. 2011; 22:1056-65. [PubMed: 21539393]

44. Cohen JA, Beaudette TT, Cohen JL, et al. Acetal-modified dextran microparticles with controlled degradation kinetics and surface functionality for gene delivery in phagocytic and non-phagocytic cells. Adv Mater. 2010; 22:3593-7. [PubMed: 20518040]

45. Han SE, Kang H, Shim GY, et al. Cationic derivatives of biocompatible hyaluronic acids for delivery of siRNA and antisense oligonucleotides. J Drug Target. 2009; 17:123-32. [PubMed: 19012052]

46. Forrest ML, Koerber JT, Pack DW. A degradable polyethylenimine derivative with low toxicity for highly efficient gene delivery. Bioconjug Chem. 2003; 14:934-40. [PubMed: 13129396]

47. Boussif O, Lezoualc'h F, Zanta MA, et al. A versatile vector for gene and oligonucleotide transfer into cells in culture and in vivo: polyethylenimine. Proc Natl Acad Sci USA. 1995; 92:7297-301. [PubMed: 7638184]

48. Abdallah B, Hassan A, Benoist C, et al. A powerful nonviral vector for in vivo gene transfer into the adult mammalian brain: polyethylenimine. Hum Gene Ther. 1996; 7:1947-54. [PubMed: 8930654]

49. Mastorakos P, Kambhampati SP, Mishra MK, et al. Hydroxyl PAMAM dendrimer-based gene vectors for transgene delivery to human retinal pigment epithelial cells. Nanoscale. 2015; 7:384556. [PubMed: 25213606]

50. Chen J, Wu C, Oupicky D. Bioreducible hyperbranched poly(amido amine)s for gene delivery. Biomacromolecules. 2009; 10:2921-7. [PubMed: 19743843]

51. Bayele HK, Sakthivel T, O’Donell M, et al. Versatile peptide dendrimers for nucleic acid delivery. J Pharm Sci. 2005; 94:446-57. [PubMed: 15614813]

52. Shmueli RB, Sunshine JC, Xu Z, et al. Gene delivery nanoparticles specific for human microvasculature and macrovasculature. Nanomedicine. 2012; 8:1200-7. [PubMed: 22306159]

53. Guerrero-Cazares H, Tzeng SY, Young NP, et al. Biodegradable polymeric nanoparticles show high efficacy and specificity at DNA delivery to human glioblastoma in vitro and in vivo. ACS Nano. 2014; 8:5141-53. [PubMed: 24766032] 
54. Poon Z, Lee JB, Morton SW, Hammond PT. Controlling in vivo stability and biodistribution in electrostatically assembled nano-particles for systemic delivery. Nano Lett. 2011; 11:2096-103. [PubMed: 21524115]

55. Jeong GJ, Byun HM, Kim JM, et al. Biodistribution and tissue expression kinetics of plasmid DNA complexed with polyethylenimines of different molecular weight and structure. J Control Release. 2007; 118:118-25. [PubMed: 17250923]

56. Harris TJ, Green JJ, Fung PW, et al. Tissue-specific gene delivery via nanoparticle coating. Biomaterials. 2010; 31:998-1006. [PubMed: 19850333]

57. Kim J, Sunshine JC, Green JJ. Differential polymer structure tunes mechanism of cellular uptake and transfection routes of poly(beta-amino ester) polyplexes in human breast cancer cells. Bioconjug Chem. 2014; 25:43-51. [PubMed: 24320687]

58. Bishop CJ, Ketola TM, Tzeng SY, et al. The effect and role of carbon atoms in poly(beta-amino ester)s for DNA binding and gene delivery. J Am Chem Soc. 2013; 135:6951-7. [PubMed: 23570657]

59. Bhise NS, Gray RS, Sunshine JC, et al. The relationship between terminal functionalization and molecular weight of a gene delivery polymer and transfection efficacy in mammary epithelial 2-D cultures and 3-D organotypic cultures. Biomaterials. 2010; 31:8088-96. [PubMed: 20674001]

60. Tzeng SY, Higgins LJ, Pomper MG, Green JJ. Student award winner in the Ph.D. category for the 2013 society for biomaterials annual meeting and exposition, April 10-13, 2013, Boston, Massachusetts: biomaterial-mediated cancer-specific DNA delivery to liver cell cultures using synthetic poly(beta-amino ester)s. J Biomed Mater Res A. 2013; 101:1837-45. [PubMed: 23559534]

61. Wagner E, Zenke M, Cotten M, et al. Transferrin-polycation conjugates as carriers for DNA uptake into cells. Proc Natl Acad Sci USA. 1990; 87:3410-14. [PubMed: 2333290]

62. Kircheis R, Kichler A, Wallner G, et al. Coupling of cell-binding ligands to polyethylenimine for targeted gene delivery. Gene therapy. 1997; 4:409-18. [PubMed: 9274717]

63. Hildebrandt IJ, Iyer M, Wagner E, Gambhir SS. Optical imaging of transferrin targeted PEI//DNA complexes in living subjects. Gene Ther. 2003; 10:758-64. [PubMed: 12704414]

64. Bellocq NC, Pun SH, Jensen GS, Davis ME. Transferrin-containing, cyclodextrin polymer-based particles for tumor-targeted gene delivery. Bioconjug Chem. 2003; 14:1122-32. [PubMed: 14624625]

65. Davis ME, Pun SH, Bellocq NC, et al. Self-assembling nucleic acid delivery vehicles via linear, water-soluble, cyclodextrin-containing polymers. Curr Med Chem. 2004; 11:179-97. [PubMed: 14754416]

66. Huang R-Q, Qu Y-H, Ke W-L, et al. Efficient gene delivery targeted to the brain using a transferrin-conjugated polyethylene-glycol-modified polyamidoamine dendrimer. FASEB J. 2007; 21:1117-25. [PubMed: 17218540]

67. Davis ME. The first targeted delivery of siRNA in humans via a self-assembling, cyclodextrin polymer-based nanoparticle: from concept to clinic. Mol Pharm. 2009; 6:659-68. [PubMed: 19267452]

68. Davis ME, Zuckerman JE, Choi CHJ, et al. Evidence of RNAi in humans from systemically administered siRNA via targeted nanoparticles. Nature. 2010; 464:1067-70. [PubMed: 20305636]

69. Zhang C, Gao S, Jiang W, et al. Targeted minicircle DNA delivery using folate-poly(ethylene glycol)-polyethylenimine as non-viral carrier. Biomaterials. 2010; 31:6075-86. [PubMed: 20488533]

70. Lee H, Lytton-Jean AKR, Chen Y, et al. Molecularly self-assembled nucleic acid nanoparticles for targeted in vivo siRNA delivery. Nat Nanotechnol. 2012; 7:389-93. [PubMed: 22659608]

71. Blessing T, Kursa M, Holzhauser R, et al. Different strategies for formation of PEGylated EGFconjugated PEI/DNA complexes for targeted gene delivery. Bioconjug Chem. 2001; 12:529-37. [PubMed: 11459457]

72. Klutz K, Schaffert D, Willhauck MJ, et al. Epidermal growth factor receptor-targeted (131)Itherapy of liver cancer following systemic delivery of the sodium iodide symporter gene. Mol Ther. 2011; 19:676-85. [PubMed: 21245850] 
73. Green JJ, Chiu E, Leshchiner ES, et al. Electrostatic ligand coatings of nanoparticles enable ligandspecific gene delivery to human primary cells. Nano Lett. 2007; 7:874-9. [PubMed: 17362046]

74. Sakae M, Ito T, Yoshihara C, et al. Highly efficient in vivo gene transfection by plasmid/PEI complexes coated by anionic PEG derivatives bearing carboxyl groups and RGD peptide. Biomed Pharmacother. 2008; 62:448-53. [PubMed: 18255250]

75. Needham CJ, Williams AK, Chew SA, et al. Engineering a polymeric gene delivery vector based on poly(ethylenimine) and hyaluronic acid. Biomacromolecules. 2012; 13:1429-37. [PubMed: 22455481]

76. Choi KY, Jeon EJ, Yoon HY, et al. Theranostic nanoparticles based on PEGylated hyaluronic acid for the diagnosis, therapy and monitoring of colon cancer. Biomaterials. 2012; 33:6186-93. [PubMed: 22687759]

77. Chiu S-J, Ueno NT, Lee RJ. Tumor-targeted gene delivery via anti-HER2 antibody (trastuzumab, Herceptin $^{\circledR}$ ) conjugated polyethylenimine. J Control Release. 2004; 97:357-69. [PubMed: 15196762]

78. Moffatt S, Papasakelariou C, Wiehle S, Cristiano R. Successful in vivo tumor targeting of prostatespecific membrane antigen with a highly efficient J591//PEI//DNA molecular conjugate. Gene Ther. 2006; 13:761-72. [PubMed: 16453011]

79. Yao YD, Sun TM, Huang SY, et al. Targeted delivery of PLK1-siRNA by ScFv suppresses Her2+ breast cancer growth and metastasis. Sci Transl Med. 2012; 4:130ra48. ra000048.

80. Akinc A, Querbes W, De S, et al. Targeted delivery of RNAi therapeutics with endogenous and exogenous ligand-based mechanisms. Mol Ther. 2010; 18:1357-64. [PubMed: 20461061]

81. Danhier F, Feron O, Préat V. To exploit the tumor microenvironment: passive and active tumor targeting of nanocarriers for anti-cancer drug delivery. J Control Release. 2010; 148:135-46. [PubMed: 20797419]

82. Kunath K, von Harpe A, Fischer D, et al. Low-molecular-weight polyethylenimine as a non-viral vector for DNA delivery: comparison of physicochemical properties, transfection efficiency and in vivo distribution with high-molecular-weight polyethylenimine. J Control Release. 2003; 89:11325. [PubMed: 12695067]

83. Ogris M, Walker G, Blessing T, et al. Tumor-targeted gene therapy: strategies for the preparation of ligand-polyethylene glycol-polyethylenimine/DNA complexes. J Control Release. 2003; 91:173-81. [PubMed: 12932649]

84. Ross JF, Chaudhuri PK, Ratnam M. Differential regulation of folate receptor isoforms in normal and malignant tissues in vivo and in established cell lines. Physiologic and clinical implications. Cancer. 1994; 73:2432-43. [PubMed: 7513252]

85. Jones HE, Gee JMW, Hutcheson IR, et al. Growth factor receptor interplay and resistance in cancer. Endocr Relat Cancer. 2006; 13:S45-51. [PubMed: 17259558]

86. Chen J, Zhou J, Lu J, et al. Significance of CD44 expression in head and neck cancer: a systemic review and meta-analysis. BMC Cancer. 2014; 14:15. [PubMed: 24410905]

87. Cheng Z, Al Zaki A, Hui JZ, et al. Multifunctional nanoparticles: cost versus benefit of adding targeting and imaging capabilities. Science. 2012; 338:903-10. [PubMed: 23161990]

88. Bhatia S, Menezes ME, Das SK, et al. Innovative approaches for enhancing cancer gene therapy. Discov Med. 2013; 15:309-17. [PubMed: 23725604]

89. Alberts, B.; Johnson, A.; Lewis, J., et al. Molecular biology of the cell. New York: Garland Science; 2002.

90. Maston GA, Evans SK, Green MR. Transcriptional regulatory elements in the human genome. Annu Rev Genomics Hum Genet. 2006; 7:29-59. [PubMed: 16719718]

91. Minn I, Menezes ME, Sarkar S, et al. Molecular-genetic imaging of cancer. Adv Cancer Res. 2014; 124:131-69. [PubMed: 25287688]

92. Struhl K. Yeast transcriptional regulatory mechanisms. Annu Rev Genet. 1995; 29:651-74. [PubMed: 8825489]

93. Lee TI, Young RA. Transcription of eukaryotic protein-coding genes. Annu Rev Genet. 2000; 34:77-137. [PubMed: 11092823]

94. Buratowski S. The basics of basal transcription by RNA polymerase II. Cell. 1994; 77:1-3. [PubMed: 8156586] 
95. Farnham PJ. Insights from genomic profiling of transcription factors. Nat Rev Genet. 2009; 10:605-16. [PubMed: 19668247]

96. Adryan B, Teichmann SA. Computational identification of site-specific transcription factors in Drosophila. Fly. 2007; 1:142-5. [PubMed: 18820428]

97. Carlberg, C.; Molnár, F. Mechanisms of gene regulation. Dordrecht: Springer; 2014. Transcription factors; p. 55-70.

98. Papadakis ED, Nicklin SA, Baker AH, White SJ. Promoters and control elements: designing expression cassettes for gene therapy. Curr Gene Ther. 2004; 4:89-113. [PubMed: 15032617]

99. Robson T, Hirst DG. Transcriptional targeting in cancer gene therapy. BioMed Res Int. 2003; 2003:110-37.

100. Schaffer DV, Fidelman NA, Dan N, Lauffenburger DA. Vector unpacking as a potential barrier for receptor-mediated polyplex gene delivery. Biotechnol Bioeng. 2000; 67:598-606. [PubMed: 10649234]

101. Vile RG, Hart IR. In vitro and in vivo targeting of gene expression to melanoma cells. Cancer Res. 1993; 53:962-7. [PubMed: 8439971]

102. Bazzoni F, Regalia E. Triggering of antitumor activity through melanoma-specific transduction of a constitutively active tumor necrosis factor (TNF) R1 chimeric receptor in the absence of TNFa. Cancer Res. 2001; 61:1050-7. [PubMed: 11221832]

103. Delmas V, Beermann F, Martinozzi S, et al. $\beta$-Catenin induces immortalization of melanocytes by suppressing p16INK4a expression and cooperates with N-Ras in melanoma development. Genes Dev. 2007; 21:2923-35. [PubMed: 18006687]

104. Gallagher SJ, Rambow F, Kumasaka M, et al. Beta-catenin inhibits melanocyte migration but induces melanoma metastasis. Oncogene. 2013; 32:2230-8. [PubMed: 22665063]

105. ŠEstÁ KovÁ B, Vachtenheim J. Distinct co-regulation of endogenous versus transfected MITFdependent tyrosinase promoter. Folia Biologica (Praha). 2006; 52:161-6.

106. Pang S, Taneja S, Dardashti K, et al. Prostate tissue specificity of the prostate-specific antigen promoter isolated from a patient with prostate cancer. Human Gene Ther. 1995; 6:1417-26. [PubMed: 8573614]

107. O'Keefe DS, Uchida A, Bacich DJ, et al. Prostate-specific suicide gene therapy using the prostate-specific membrane antigen promoter and enhancer. Prostate. 2000; 45:149-57. [PubMed: 11027414]

108. Zhang J, Thomas TZ, Kasper S, Matusik RJ. A small composite probasin promoter confers high levels of prostate-specific gene expression through regulation by androgens and glucocorticoids in vitro and in vivo 1. Endocrinology. 2000; 141:4698-710. [PubMed: 11108285]

109. Song J, Pang S, Lu Y, et al. Gene silencing in androgen-responsive prostate cancer cells from the tissue-specific prostate-specific antigen promoter. Cancer Res. 2004; 64:7661-3. [PubMed: 15520164]

110. Nettelbeck DM, Jérôme V, Müller R. Gene therapy: designer promoters for tumour targeting. Trends Genet. 2000; 16:174-81. [PubMed: 10729833]

111. Harrington KJ, Linardakis E, Vile RG. Transcriptional control: an essential component of cancer gene therapy strategies? Adv Drug Deliv Rev. 2000; 44:167-84. [PubMed: 11072113]

112. Su Z-Z, Shi Y, Fisher PB. Subtraction hybridization identifies a transformation progressionassociated gene PEG-3 with sequence homology to a growth arrest and DNA damage-inducible gene. Proc Natl Acad Sci USA. 1997; 94:9125-30. [PubMed: 9256446]

113. Su Z-Z, Sarkar D, Emdad L, et al. Targeting gene expression selectively in cancer cells by using the progression-elevated gene-3 promoter. Proc Natl Acad Sci USA. 2005; 102:1059-64. [PubMed: 15647352]

114. Hyo-eun CB, Gabrielson KL, Laterra J, et al. Tumor-specific imaging through progression elevated gene-3 promoter-driven gene expression. Nat Med. 2011; 17:123-9. [PubMed: 21151140]

115. Pan CX, Koeneman KS. A novel tumor-specific gene therapy for bladder cancer. Med Hypotheses. 1999; 53:130-5. [PubMed: 10532707]

116. Ambrosini G, Adida C, Altieri DC. A novel anti-apoptosis gene, survivin, expressed in cancer and lymphoma. Nat Med. 1997; 3:917-21. [PubMed: 9256286] 
117. Ambrosini G, Adida C, Sirugo G, Altieri DC. Induction of apoptosis and inhibition of cell proliferation by survivin gene targeting. J Biol Chem. 1998; 273:11177-82. [PubMed: 9556606]

118. Lee S-G, Su Z-Z, Emdad L, et al. Astrocyte elevated gene-1 (AEG-1) is a target gene of oncogenic Ha-ras requiring phosphatidylinositol 3-kinase and c-Myc. Proc Natl Acad Sci USA. 2006; 103:17390-5. [PubMed: 17088530]

119. Bhatnagar A, Wang Y, Mease RC, et al. AEG-1 promoter-mediated imaging of prostate cancer. Cancer Res. 2014; 74:5772-81. [PubMed: 25145668]

120. Hu BG, Liu LP, Chen GG, et al. Therapeutic efficacy of improved a-fetoprotein promotermediated tBid delivered by folate-PEI600-cyclodextrin nanopolymer vector in hepatocellular carcinoma. Exp Cell Res. 2014; 324:183-91. [PubMed: 24726886]

121. Huang Y-H, Zugates GT, Peng W, et al. Nanoparticle-delivered suicide gene therapy effectively reduces ovarian tumor burden in mice. Cancer Res. 2009; 69:6184-91. [PubMed: 19643734]

122. Gao P, Wang R, Shen JJ, et al. Hypoxia-inducible enhancer/a-fetoprotein promoter-driven RNA interference targeting STK15 suppresses proliferation and induces apoptosis in human hepatocellular carcinoma cells. Cancer Sci. 2008; 99:2209-17. [PubMed: 18803637]

123. Jaggar RT, Chan HY, Harris AL, Bicknell R. Endothelial cell-specific expression of tumor necrosis factor-a from the KDR or E-selectin promoters following retroviral delivery. Hum Gene Ther. 1997; 8:2239-47. [PubMed: 9449377]

124. Harris JD, Gutierrez AA, Hurst HC, et al. Gene therapy for cancer using tumour-specific prodrug activation. Gene Ther. 1994; 1:170-5. [PubMed: 7584078]

125. Parr MJ, Manome Y, Tanaka T, et al. Tumor-selective transgene expression in vivo mediated by an E2F-responsive adenoviral vector. Nat Med. 1997; 3:1145-9. [PubMed: 9334729]

126. Goverdhana S, Puntel M, Xiong W, et al. Regulatable gene expression systems for gene therapy applications: progress and future challenges. Mol Ther. 2005; 12:189-211. [PubMed: 15946903]

127. Voellmy R. Gene switches for deliberate regulation of transgene expression: recent advances in system development and uses. J Genet Syndr Gene Ther. 2011; 2:107.

128. Makarov, SS. Gene therapy for rheumatoid arthritis: preclinical studies. In: Evans, CH.; Robbins, PD., editors. Gene therapy in inflammatory diseases. Basel: Birkhäuser; 2000. p. 13-34.

129. Bateman BT, Donegan NP, Jarry TM, et al. Evaluation of a tetracycline-inducible promoter in Staphylococcus aureus in vitro and in vivo and its application in demonstrating the role of sigB in microcolony formation. Infect Immun. 2001; 69:7851-7. [PubMed: 11705967]

130. Anton M, Gomaa IEO, von Lukowicz T, et al. Optimization of radiation controlled gene expression by adenoviral vectors in vitro. Cancer Gene Ther. 2005; 12:640-6. [PubMed: 15803145]

131. Xiong J, Sun WJ, Wang WF, et al. Novel, chimeric, cancer-specific, and radiation-inducible gene promoters for suicide gene therapy of cancer. Cancer. 2012; 118:536-48. [PubMed: 21717442]

132. Kawashita Y, Ohtsuru A, Kaneda Y, et al. Regression of hepatocellular carcinoma in vitro and in vivo by radiosensitizing suicide gene therapy under the inducible and spatial control of radiation. Hum Gene Ther. 1999; 10:1509-19. [PubMed: 10395376]

133. Manome Y, Kunieda T, Wen PY, et al. Transgene expression in malignant glioma using a replication-defective adenoviral vector containing the Egr-1 promoter: activation by ionizing radiation or uptake of radioactive iododeoxyuridine. Hum Gene Ther. 1998; 9:1409-17. [PubMed: 9681412]

134. Buchholz, DR. Tet-on binary systems for tissue-specific and inducible transgene expression. In: Hoppler, S.; Vize, PD., editors. Xenopus protocol: post-genomic approaches. 2. New York: Humana Press; 2012. p. 265-75.

135. Das B, Brown DD. Controlling transgene expression to study Xenopus laevis metamorphosis. Proc Natl Acad Sci USA. 2004; 101:4839-42. [PubMed: 15047886]

136. Smith-Arica JR, Morelli AE, Larregina AT, et al. Cell-type-specific and regulatable transgenesis in the adult brain: adenovirus-encoded combined transcriptional targeting and inducible transgene expression. Mol Ther. 2000; 2:579-87. [PubMed: 11124058]

137. Datta R, Rubin E, Sukhatme V, et al. Ionizing radiation activates transcription of the EGR1 gene via CArG elements. Proc Natl Acad Sci. 1992; 89:10149-53. [PubMed: 1332031] 
138. Cooper TA, Mattox W. The regulation of splice-site selection, and its role in human disease. Am J Hum Genet. 1997; 61:259-66. [PubMed: 9311728]

139. Zheng Z-M. Regulation of alternative RNA splicing by exon definition and exon sequences in viral and mammalian gene expression. J Biomed Sci. 2004; 11:278-94. [PubMed: 15067211]

140. Hayes GM, Carpenito C, Davis PD, et al. Alternative splicing as a novel of means of regulating the expression of therapeutic genes. Cancer Gene Ther. 2002; 9:133-41. [PubMed: 11857030]

141. Günthert U, Hofmann M, Rudy W, et al. A new variant of glycoprotein CD44 confers metastatic potential to rat carcinoma cells. Cell. 1991; 65:13-24. [PubMed: 1707342]

142. Mochizuki H, Nishi T, Bruner JM, et al. Alternative splicing of neurofibromatosis type 1 gene transcript in malignant brain tumors: PCR analysis of frozen-section mRNA. Mol Carcinog. 1992; 6:83-7. [PubMed: 1388685]

143. Knapinska AM, Irizarry-Barreto P, Adusumalli S, et al. Molecular mechanisms regulating mRNA stability: physiological and pathological significance. Curr Genomics. 2005; 6:471-86.

144. Tuschl T. RNA interference and small interfering RNAs. Chembiochem. 2001; 2:239-45. [PubMed: 11828450]

145. Zeng Y, Yi R, Cullen BR. MicroRNAs and small interfering RNAs can inhibit mRNA expression by similar mechanisms. Proc Natl Acad Sci USA. 2003; 100:9779-84. [PubMed: 12902540]

146. Devi GR. siRNA-based approaches in cancer therapy. Cancer Gene Ther. 2006; 13:819-29. [PubMed: 16424918]

147. Grzmil M, Thelen P, Hemmerlein B, et al. Bax inhibitor-1 is overexpressed in prostate cancer and its specific down-regulation by RNA interference leads to cell death in human prostate carcinoma cells. Am J Pathol. 2003; 163:543-52. [PubMed: 12875974]

148. Akar U, Chaves-Reyez A, Barria M, et al. Silencing of Bcl-2 expression by small interfering RNA induces autophagic cell death in MCF-7 breast cancer cells. Autophagy. 2008; 4:669-79. [PubMed: 18424910]

149. Pecot CV, Wu SY, Bellister S, et al. Therapeutic silencing of KRAS using systemically delivered siRNAs. Mol Cancer Ther. 2014; 13:2876-85. [PubMed: 25281617]

150. Butz K, Ristriani T, Hengstermann A, et al. siRNA targeting of the viral E6 oncogene efficiently kills human papillomavirus-positive cancer cells. Oncogene. 2003; 22:5938-45. [PubMed: 12955072]

151. Urban-Klein B, Werth S, Abuharbeid S, et al. RNAi-mediated gene-targeting through systemic application of polyethylenimine (PEI)-complexed siRNA in vivo. Gene Ther. 2005; 12:461-6. [PubMed: 15616603]

152. Yokota J, Yamamoto T, Miyajima N, et al. Genetic alterations of the c-erbB-2 oncogene occur frequently in tubular adenocarcinoma of the stomach and are often accompanied by amplification of the v-erbA homologue. Oncogene. 1988; 2:283-7. [PubMed: 3281095]

153. Menard S, Casalini P, Campiglio M, et al. HER2 overexpression in various tumor types, focussing on its relationship to the development of invasive breast cancer. Ann Oncol. 2001; 12:S15-19. [PubMed: 11521715]

154. Slamon DJ, Godolphin W, Jones LA, et al. Studies of the HER-2/neu proto-oncogene in human breast and ovarian cancer. Science. 1989; 244:707-12. [PubMed: 2470152]

155. Bader AG, Brown D, Winkler M. The promise of microRNA replacement therapy. Cancer Res. 2010; 70:7027-30. [PubMed: 20807816]

156. Barh D, Malhotra R, Ravi B, Sindhurani P. MicroRNA let-7: an emerging next-generation cancer therapeutic. Curr Oncol. 2010; 17:70-80. [PubMed: 20179807]

157. Welch C, Chen Y, Stallings RL. MicroRNA-34a functions as a potential tumor suppressor by inducing apoptosis in neuroblastoma cells. Oncogene. 2007; 26:5017-22. [PubMed: 17297439]

158. Chang T-C, Wentzel EA, Kent OA, et al. Transactivation of miR-34a by p53 broadly influences gene expression and promotes apoptosis. Mol Cell. 2007; 26:745-52. [PubMed: 17540599]

159. Li N, Fu H, Tie Y, et al. miR-34a inhibits migration and invasion by down-regulation of c-Met expression in human hepatocellular carcinoma cells. Cancer Lett. 2009; 275:44-53. [PubMed: 19006648] 
160. Chen Y, Zhu X, Zhang X, et al. Nanoparticles modified with tumor-targeting scFv deliver siRNA and miRNA for cancer therapy. Mol Ther. 2010; 18:1650-6. [PubMed: 20606648]

161. Ohno, S-i; Takanashi, M.; Sudo, K., et al. Systemically injected exosomes targeted to EGFR deliver antitumor microRNA to breast cancer cells. Mol Ther. 2013; 21:185-91. [PubMed: 23032975]

162. Zhao XD, Zhang W, Liang HJ, Ji WY. Overexpression of miR-155 promotes proliferation and invasion of human laryngeal squamous cell carcinoma via targeting SOCS1 and STAT3. PLoS One. 2013; 8:e56395. [PubMed: 23437123]

163. Wang Z, Rao DD, Senzer N, Nemunaitis J. RNA interference and cancer therapy. Pharm Res. 2011; 28:2983-95. [PubMed: 22009588]

164. Meric F, Hunt KK. Translation initiation in cancer: a novel target for therapy 1 FM is supported by The University of Texas MD Anderson Cancer Center Physician-Scientist Program and by NIH Grant 1KO8-CA 91895-01. KKH is supported by Department of Defense Award DAMD-17-97-1-7162. 1. Mol Cancer Ther. 2002; 1:971-9. [PubMed: 12481419]

165. Darveau A, Pelletier J, Sonenberg N. Differential efficiencies of in vitro translation of mouse cmyc transcripts differing in the 5'untranslated region. Proc Natl Acad Sci USA. 1985; 82:231519. [PubMed: 3857582]

166. DeFatta RJ, Li Y, De Benedetti A. Selective killing of cancer cells based on translational control of a suicide gene. Cancer Gene Ther. 2002; 9:573-8. [PubMed: 12082457]

167. Koromilas AE, Lazaris-Karatzas A, Sonenberg N. mRNAs containing extensive secondary structure in their $5^{\prime}$ non-coding region translate efficiently in cells overexpressing initiation factor eIF-4E. EMBO J. 1992; 11:4153. [PubMed: 1396596]

168. Crew JP, Fuggle S, Bicknell R, et al. Eukaryotic initiation factor-4E in superficial and muscle invasive bladder cancer and its correlation with vascular endothelial growth factor expression and tumour progression. Br J Cancer. 2000; 82:161-6. [PubMed: 10638984]

169. Kerekatte V, Smiley K, Hu B, et al. The proto-oncogene/translation factor eIF4E: a survey of its expression in breast carcinomas. Int J Cancer. 1995; 64:27-31. [PubMed: 7665244]

170. Wang R, Geng J, Wang JH, et al. Overexpression of eukaryotic initiation factor 4E (eIF4E) and its clinical significance in lung adenocarcinoma. Lung Cancer. 2009; 66:237-44. [PubMed: 19261348]

171. Kevil C, Carter P, Hu B, DeBenedetti A. Translational enhancement of FGF-2 by eIF-4 factors, and alternate utilization of CUG and AUG codons for translation initiation. Oncogene. 1995; 11:2339-48. [PubMed: 8570185]

172. Wang Z, Sun Y. Targeting p53 for novel anticancer therapy. Transl Oncol. 2010; 3:1-12. [PubMed: 20165689]

173. Roth JA. Adenovirus p53 gene therapy. Expert Opin Biol Ther. 2006; 6:55-61. [PubMed: 16370914]

174. Lemke J, Von Karstedt S, Zinngrebe J, Walczak H. Getting TRAIL back on track for cancer therapy. Cell Death Differ. 2014; 21:1350-64. [PubMed: 24948009]

175. Walczak H, Miller RE, Ariail K, et al. Tumoricidal activity of tumor necrosis factor-related apoptosis-inducing ligand in vivo. Nat Med. 1999; 5:157-63. [PubMed: 9930862]

176. Ashkenazi A. Directing cancer cells to self-destruct with pro-apoptotic receptor agonists. Nat Rev Drug Discov. 2008; 7:1001-12. [PubMed: 18989337]

177. Komarova S, Kawakami Y, Stoff-Khalili MA, et al. Mesenchymal progenitor cells as cellular vehicles for delivery of oncolytic adenoviruses. Mol Cancer Ther. 2006; 5:755-66. [PubMed: 16546991]

178. Studeny M, Marini FC, Champlin RE, et al. Bone marrow-derived mesenchymal stem cells as vehicles for interferon- $\beta$ delivery into tumors. Cancer Res. 2002; 62:3603-8. [PubMed: 12097260]

179. Aboody KS, Brown A, Rainov NG, et al. Neural stem cells display extensive tropism for pathology in adult brain: evidence from intracranial gliomas. Proc Natl Acad Sci USA. 2000; 97:12846-51. [PubMed: 11070094] 
180. Lombardo Y, Scopelliti A, Cammareri P, et al. Bone morphogenetic protein 4 induces differentiation of colorectal cancer stem cells and increases their response to chemotherapy in mice. Gastroenterology. 2011; 140:297-309. [PubMed: 20951698]

181. Zhang L, Sun H, Zhao F, et al. BMP4 administration induces differentiation of CD133+ hepatic cancer stem cells, blocking their contributions to hepatocellular carcinoma. Cancer Res. 2012; 72:4276-85. [PubMed: 22773665]

182. Piccirillo SGM, Reynolds BA, Zanetti N, et al. Bone morphogenetic proteins inhibit the tumorigenic potential of human brain tumour-initiating cells. Nature. 2006; 444:761-5. [PubMed: 17151667]

183. Li Q, Wijesekera O, Salas SJ, et al. Mesenchymal stem cells from human fat engineered to secrete BMP4 are nononcogenic, suppress brain cancer, and prolong survival. Clin Cancer Res. 2014; 20:2375-87. [PubMed: 24789034]

184. Hanna N, Ohana P, Konikoff FM, et al. Phase 1/2a, dose-escalation, safety, pharmacokinetic and preliminary efficacy study of intratumoral administration of BC-819 in patients with unresectable pancreatic cancer. Cancer Gene Ther. 2012; 19:374-81. [PubMed: 22498722]

185. Buscail L, Bournet B, Vernejoul F, et al. First-in-man phase I clinical trial of gene therapy for advanced pancreatic cancer: safety, biodistribution and preliminary clinical findings. Mol Ther. 2015; 23:779-89. [PubMed: 25586689]

186. Alvarez RD, Sill MW, Davidson SA, et al. A phase II trial of intraperitoneal EGEN-001, an IL-12 plasmid formulated with PEG-PEI-cholesterol lipopolymer in the treatment of persistent or recurrent epithelial ovarian, fallopian tube or primary peritoneal cancer: A Gynecologic Oncology Group study. Gynecol Oncol. 2014; 133:433-8. [PubMed: 24708919]

187. Francis SM, Taylor CA, Tang T, et al. SNS01-T modulation of eIF5A inhibits B-cell cancer progression and synergizes with bortezomib and lenalidomide. Mol Ther. 2014; 22:1643-52. [PubMed: 24569836]

188. Knop K, Hoogenboom R, Fischer D, Schubert US. Poly(ethylene glycol) in drug delivery: pros and cons as well as potential alternatives. Angew Chem (International ed in English). 2010; 49:6288-308.

189. Yin H, Kanasty RL, Eltoukhy AA, et al. Non-viral vectors for gene-based therapy. Nat Rev Genet. 2014; 15:541-55. [PubMed: 25022906] 


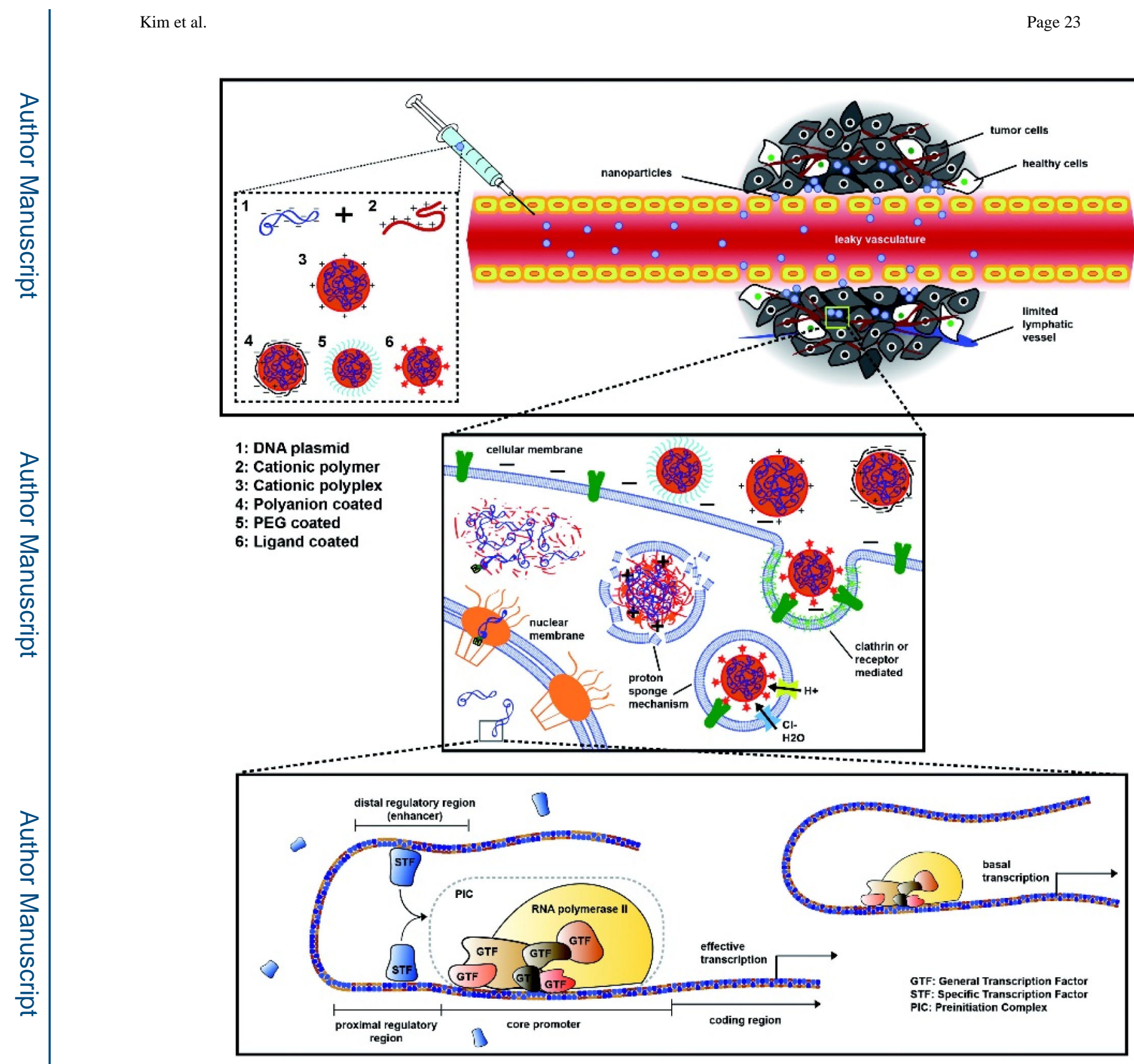

Figure 1.

Overall scheme of gene delivery to cancer cells using targeted polymeric nanoparticles. Three broad categories of targeting include biophysical targeting, ligand-mediated targeting, and transcriptional targeting. 

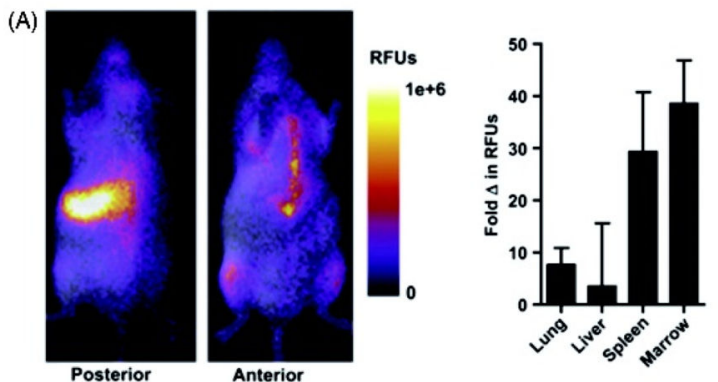
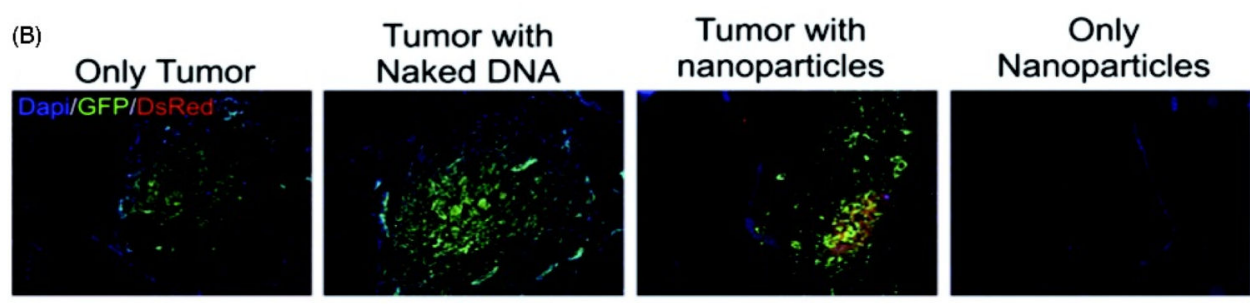

(C)
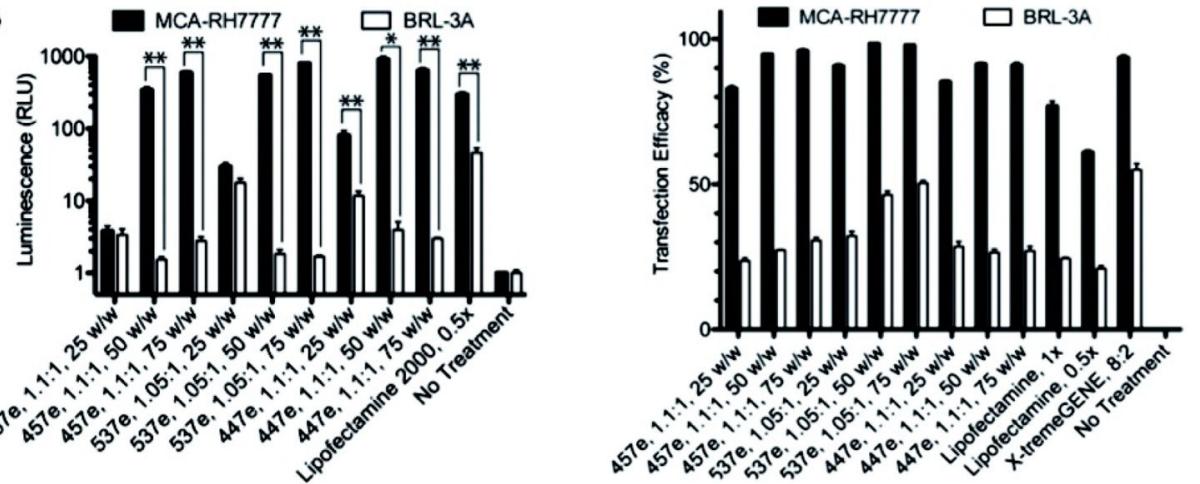

Figure 2.

Biomaterial-mediated tissue- and cell-specificity of nanoparticles. (A) Accumulation of PBAE nanoparticles coated with poly (glutamic acid) chain terminating with additional cationic amino acid residues in spleen and bone marrow. (B) Selective PBAE transfection of brain tumor initiating cells over fetal neural stem cells in vivo (delivery of dsRed to BTIC labeled with GFP; only nanoparticles is a control group with nanoparticles but no tumor) and of (C) hepatoma cells over hepatocytes in separate cultures (left) and in co-culture (right). Reprinted with permission from Elsevier: Biomaterials. 2010;31:998-1006, American Chemical Society: ACS Nano. 2014;8(5):5141-53, and John Wiley and Sons: Journal of Biomedical Materials Research. 2013;101(7):1837-45 [53,56,60]. 


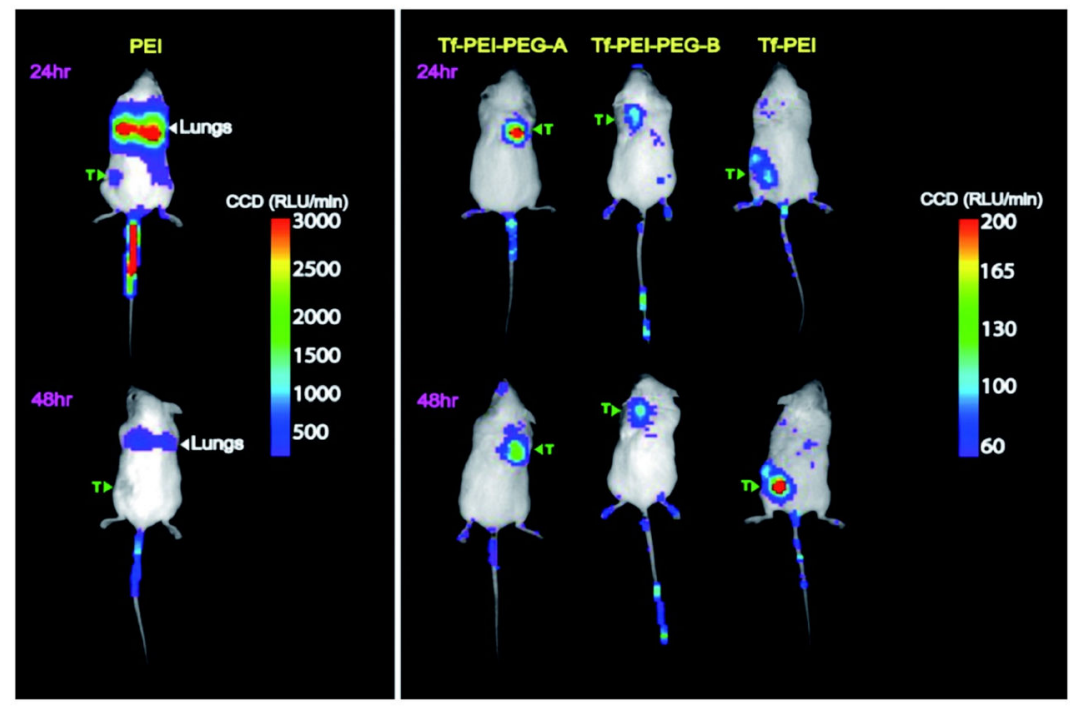

Figure 3.

Bioluminescent imaging of mice with subcutaneous neuroblastoma xenograft tumors (T) was used to assess improvements in tumor targeting following tail vein injection at 24 and $48 \mathrm{~h}$. Conjugation of transferrin to PEI and PEI-PEG was shown to reduce off-target transfection and improve tumor specific expression at $48 \mathrm{~h}$ when compared to untargeted PEI. Reprinted by permission from Nature Publishing Group: Gene Therapy. 2003;10:758764, copyright 2003 [63]. 
(A)

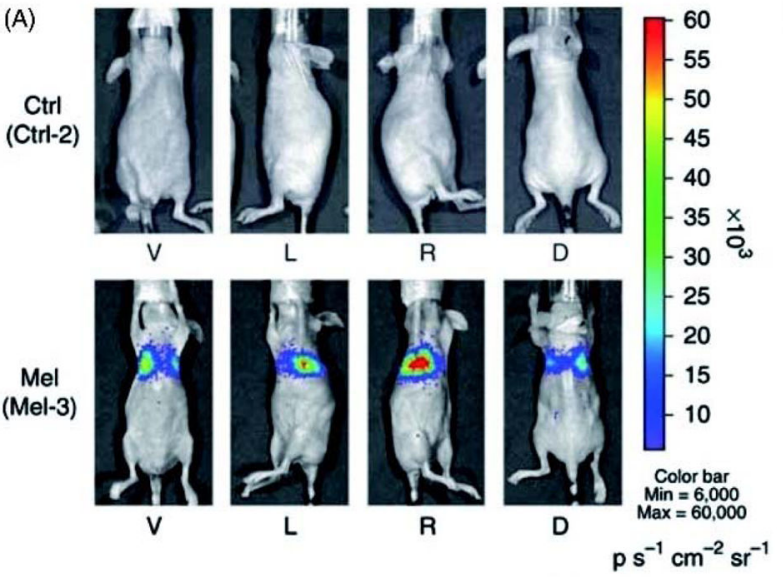

(B)
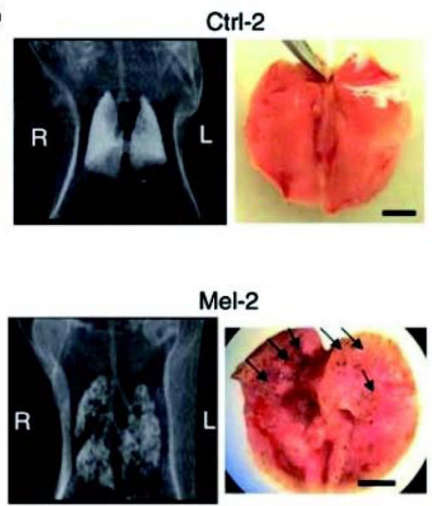

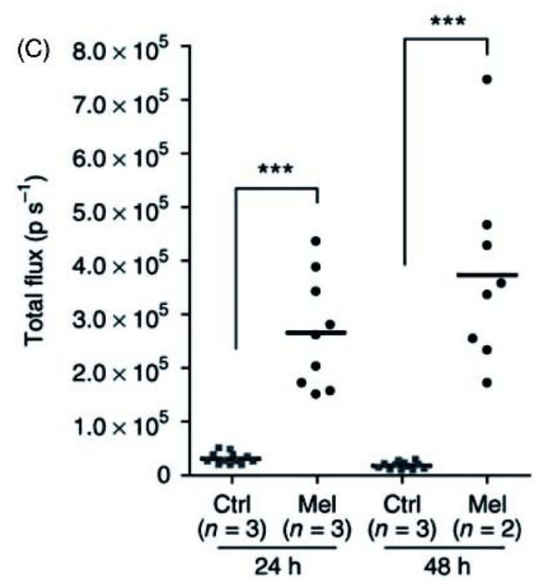

Figure 4.

(A) Bioluminescence imaging showing cancer-specific expression of firefly luciferase gene in a representative of the metastatic melanoma group (Mel-3) and no expression in a healthy control mouse (Ctrl-2). (B) Computed tomography imaging and gross anatomical views of the lung from a healthy control mouse (Ctrl-2) and one representative of the metastatic melanoma group (Mel-2). Black arrows are pointing toward the metastatic nodules in the lung. Scale bars: $5 \mathrm{~mm}$. (C) Quantification of bioluminescence imaging signal intensity in the control group (Ctrl) and metastatic melanoma group at 24 and $48 \mathrm{~h}$ following i.v. administration of the pPEG-Luc-PEI polyplex. Quantified values are shown in total flux. $* * * p<0.0001$. Reprinted with permission from Nature Publishing Group: Nat Med.

2011;17(1):123-9 [114]. 


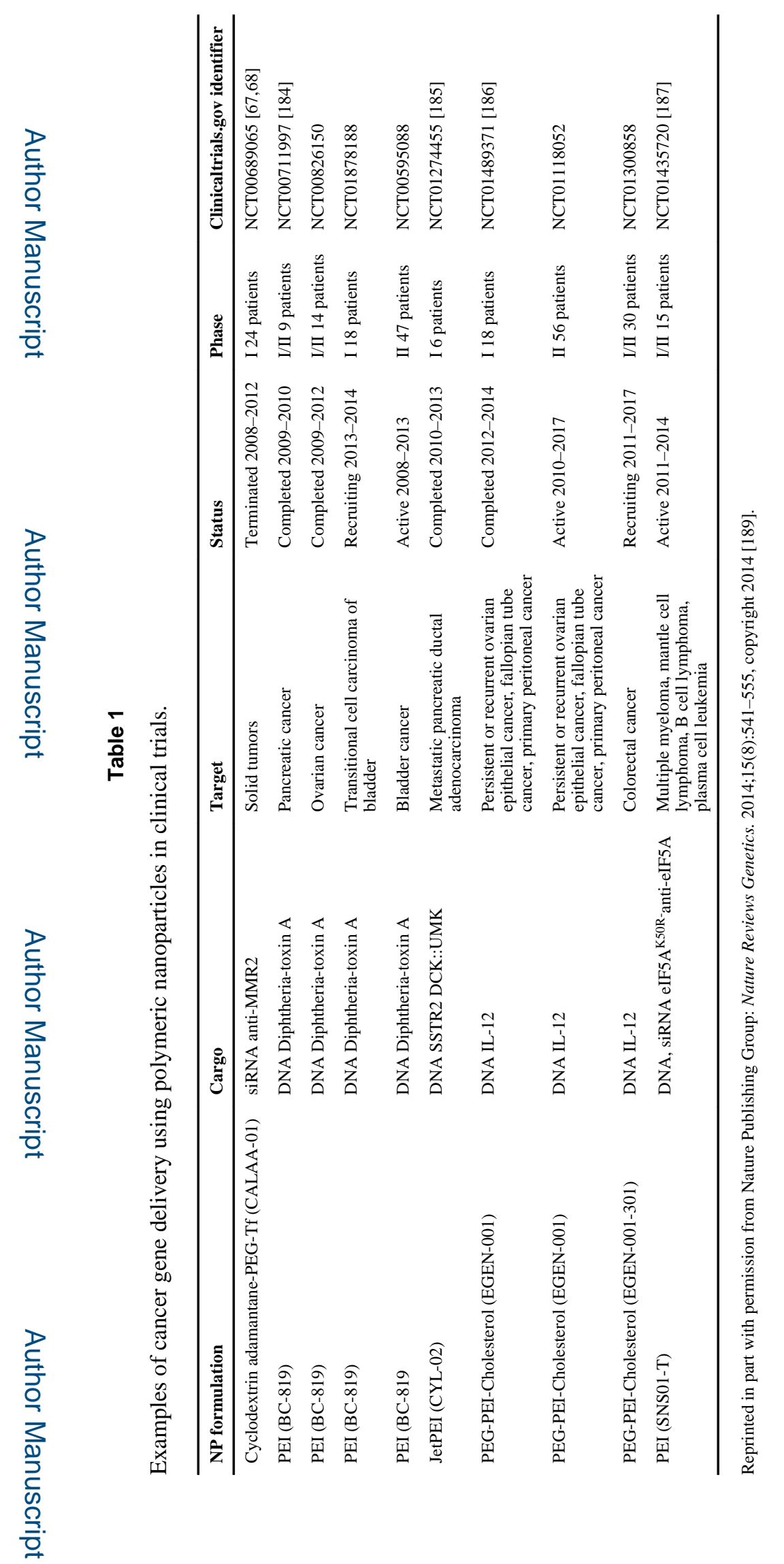

J Drug Target. Author manuscript; available in PMC 2015 December 30. 


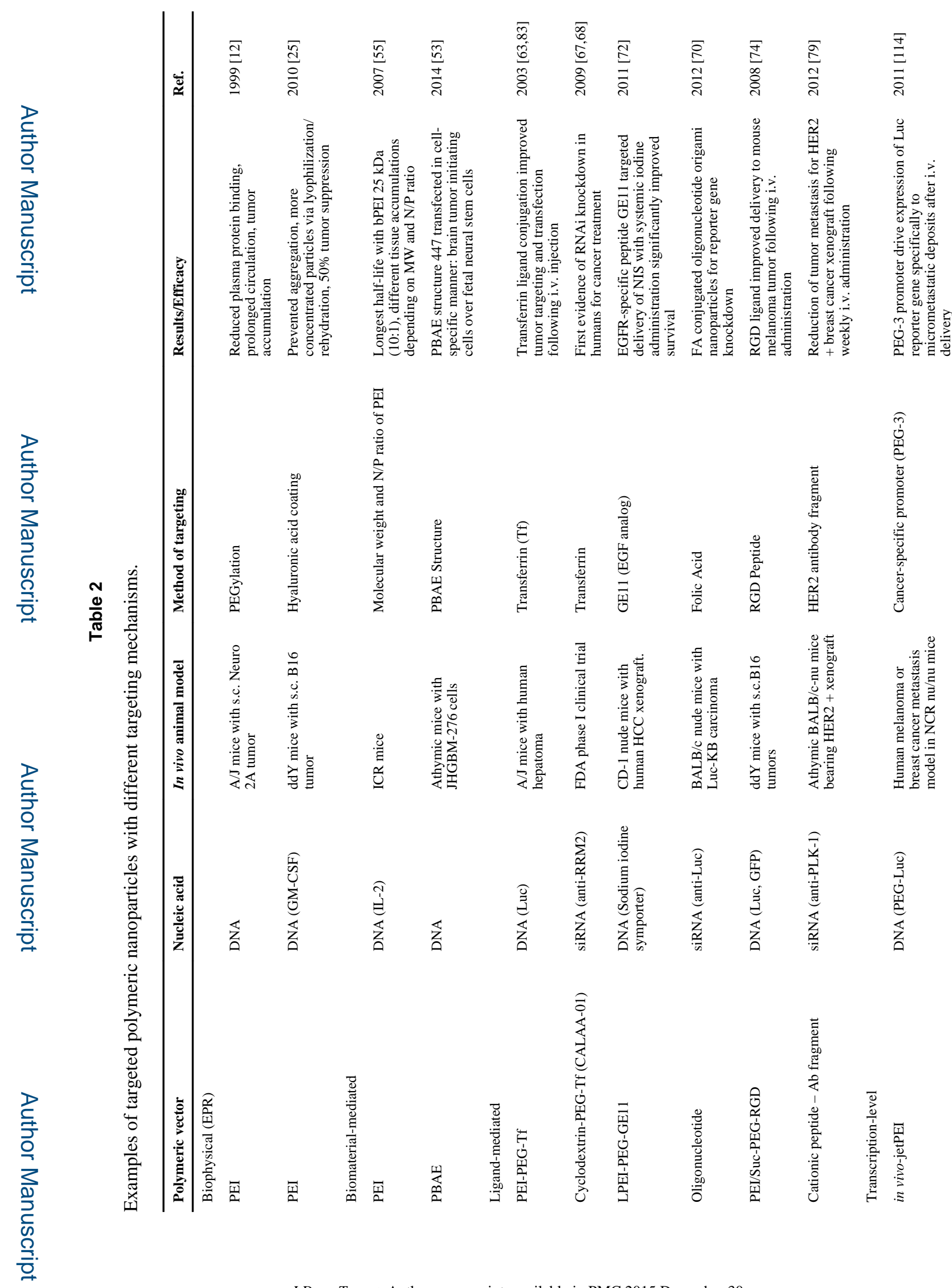

J Drug Target. Author manuscript; available in PMC 2015 December 30. 
Kim et al.

Page 29

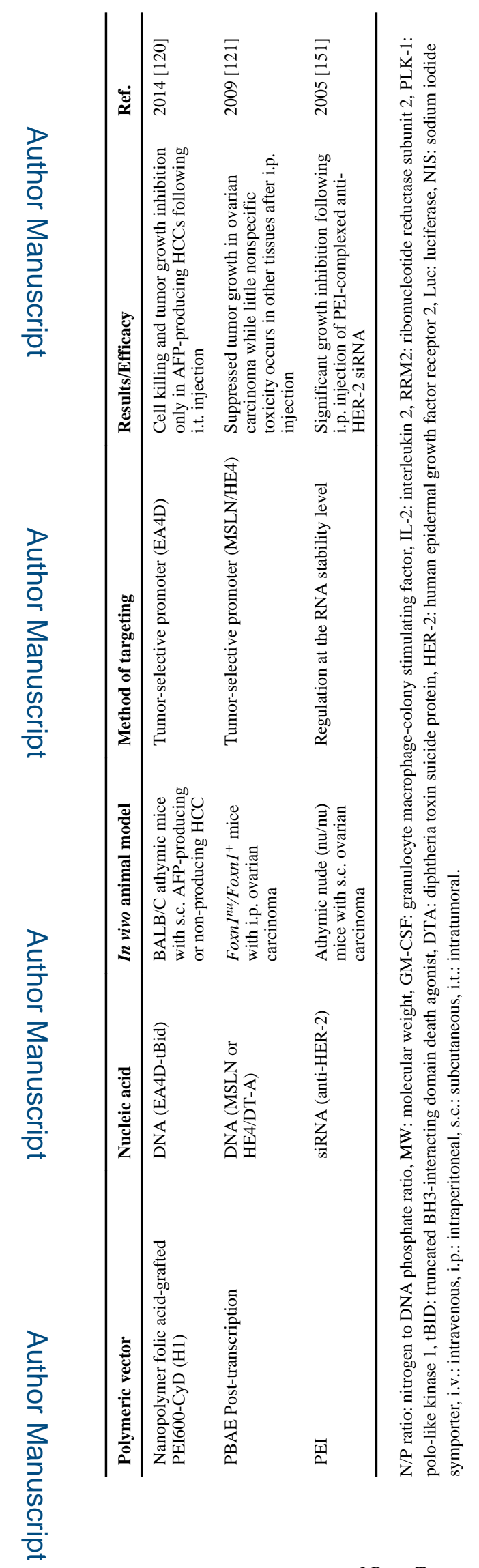

J Drug Target. Author manuscript; available in PMC 2015 December 30. 